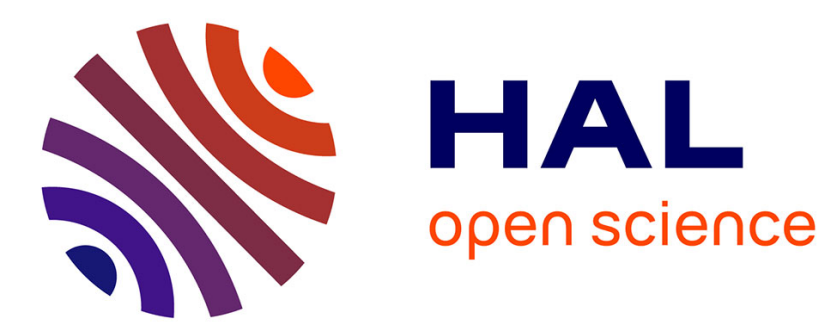

\title{
Astral Sciences in Early Imperial China:
}

\author{
Daniel Patrick Morgan
}

\section{To cite this version:}

Daniel Patrick Morgan. Astral Sciences in Early Imperial China: : Translations with Original Chinese.

Cambridge University Press, 2017, 9781107139022. halshs-01563546

\section{HAL Id: halshs-01563546 \\ https://shs.hal.science/halshs-01563546}

Submitted on 5 Dec 2017

HAL is a multi-disciplinary open access archive for the deposit and dissemination of scientific research documents, whether they are published or not. The documents may come from teaching and research institutions in France or abroad, or from public or private research centers.
L'archive ouverte pluridisciplinaire HAL, est destinée au dépôt et à la diffusion de documents scientifiques de niveau recherche, publiés ou non, émanant des établissements d'enseignement et de recherche français ou étrangers, des laboratoires publics ou privés.

\section{(1)(1) $\$(0)$}

Distributed under a Creative Commons Attribution - NonCommercial - ShareAlikel 4.0 


\title{
Astral Sciences in Early Imperial China Translations with Original Chinese
}

\author{
Daniel Patrick Morgan
}

\section{Introduction}

Mencius 孟子, IVB.26

孟子曰:「天下之言性也, 則故而已矣。故者以利為本。所惡於 智者, 為其鳌也。如智者若禹之行水也, 則無惡於智矣。禹之行 水也, 行其所無事也。如智者亦行其所無事, 則智亦大矣。天之 高也, 星辰之遠也, 苟求其故, 千歲之日至, 可坐而致也。」

Mencius said, 'All discussion of the nature [of things] in the worldbelow-heaven comes down to precedence/reason $(g u)$, and nothing else. Fundamental to precedent-reasoning $(g u)$ is the sharp/smoothness [with which it cuts]. What is detestable about philosophers is their chiselling their way through (to their preferred conclusions). If philosophers could simply act as Yu did in guiding the [flood] waters, then there would be nothing to detest of them: Yu guided the water by simply conducting it where it was wont to go without imposition; if philosophers too could act without imposition, then great indeed would their philosophy be. Whatever the heights of the heavens and the distance of the stars, if one seeks out former instances $(g u)$, then one can render the solstices of a thousand years without stirring from one's seat'. 


\section{Chapter 1}

Zhouyi zhushu 周易注疏, 8.166b:

古者包犧氏之王天下也，仰則觀象於天，俯則觀法於地，觀鳥獸 之文, 與地之宜, 近取諸身, 遠取諸物, 於是始作八卦, 以通神 明之德, 以類萬物之情。

In antiquity, when [Fu]xi reigned as king over the subcelestial realm, [he] looked up and observed (guan) the signs (xiang) in heaven, [he] looked down and observed the principles $(f a)$ of earth, and [he] observed the patterns (wen) of birds and beasts and [their] suitabilities with the earth. [He] took what was near at hand from himself, [he] took what was far away from things, and from this [he] invented (shizuo) the eight trigrams to enter into connection with the virtue of the light of the spirits and to categorise the circumstances of the myriad things. ${ }^{1}$

Han shu 漢書, 21A.973:

曆數之起上矣。傳述顓頊命南正重司天, 火正黎司地, 其後三苗 亂德, 二官咸廢, 而閏餘乘次, 孟陬殄滅, 攝提失方。堯復育重、 黎之後, 使纂其業, 故書曰:

The origin of li numbers lies in high [antiquity]. Tradition states that [Thearch] Zhuanxu commanded Chong, the Rector of the South, to administer Heaven, and Li, the Rector of Fire, to administer Earth. Afterwards, the Sanmiao [tribes] corrupted their virtue, and both offices were abandoned. [As a result,] the intercalary remainder got out of order, the meng-zou [correspondence] was quashed into extinction, and the Regulators went in the wrong direction. [Sage King] Yao re-educated Chong and Li's descendants that they might inherit their patrimony. Thus do the Documents say:

「乃命羲、和，欽若昊天，曆象日月星辰，敬授民時。」「歲三 百有六旬有六日, 以閏月定四時成歲, 允釐百官, 衆功皆美。」 'And so [Yao] charged $\mathrm{Xi}$ and $\mathrm{He}$ : "In reverent accordance with prodigious heaven, [thou shalt] $l i$ and xiang the sun, moon and stars and respectfully grant human seasons/time ... The agricultural year (sui) has three hundred, sixty and six days, [so] fix the four seasons and complete the agricultural year by means of intercalary month. Earnestly regulate [all the] officials, and all [thy] many achievements shall be resplendent". 2

其後以授舜曰: 「咨爾舜，天之曆數在爾躬。」「舜亦以命禹。」 Afterwards, [Yao] transferred [the throne] to Shun in kind, saying 'Oh, thou, Shun! The li numbers of heaven rest in thy person', and 'so too did Shun command $\mathrm{Yu}$ [the Great] in kind'.

至周武王訪箕子, 箕子言大法九章, 而五紀明曆法。故自殷周, 皆創業改制, 咸正曆紀, 服色從之, 順其時氣, 以應天道。

When King Wu of Zhou (r. 1049/45-1043 BCE) called on Jizi, Jizi spoke of the great method in nine chapters and illuminated li method

\footnotetext{
${ }^{1}$ Tr. modified from Wilhelm (1967, 328-29).

${ }^{2}$ Shangshu zhushu, 2.21a.

${ }^{3}$ Analects XX.1; tr. modified from Lau (2000, 201). Here the Book of Documents 'Dayu mo' chapter reads: 'We luxuriate in thy virtue and esteem thy great achievements; the $l i$ numbers of heaven rest in thy person, and thou shalt eventually ascend [to the throne] of the great sovereign' (Shangshu zhushu, 4.55b).
} 
[via] the five regulators (year, moon, day, stars and numbers). ${ }^{4}$ Thus, of all those since the Yin (?-1045 BCE) and [Western] Zhou (1045$771 \mathrm{BCE}$ ) who have founded patrimony and initiated reform - all of them rectified the $l i$ regulators (ji) and conformed the colour of court costume to [the $l i$ ], obeying the qi of the times in response to the dao of heaven.

三代既沒，五伯之末，史官喪紀，疇人子弟分散，或在夷狄，故 其所記, 有黃帝、顓頊、夏、殷、周及魯曆。戰國擾攘, 秦兼天 下, 未皇暇也, 亦頗推五勝, 而自以為獲水德, 乃以十月為正, 色上黑。

After the Three Dynasties (Xia, Yin-Shang and Zhou) had disappeared, and at the end of the Five Earls (770-481 BCE), the Clerk's Office (shiguan) lost its regulation/discipline (ji), and the disciples of its hereditary practitioners were dispersed, some to the Yi and Di [tribes], which is why their records [leave us with] the Yellow Emperor, Zhuanxu, Xia, Yin, Zhou and Lu $l i$ (the 'six ancient $l i$ '). ${ }^{5}$ In the tumult of the Warring States (480-221 BCE), the Qin [managed to] consolidate the word-under-heaven but not pacify it. [The Qin Empire,] for its part, rather pushed the five conquests [theory], believing themselves to have obtained the virtue of water, and so took month $\mathrm{X}$ as the first [month of the civil calendar] and promoted the colour black.

Hou Han shu 後漢書, zhi 3, 3057:

夫曆有聖人之德六焉：以本氣者尚其體, 以綜數者尚其文, 以考 類者尚其象, 以作事者尚其時, 以占往者尚其源, 以知來者尚其 流。

$L i$ is possessed of (the?) six virtues of the sage: venerating [heaven's] body/ies ( $t i)$ through the comprehension of $q i$; venerating [heaven's] patterns (wen) through the synthesis of numbers; venerating [heaven's] signs (xiang) through the investigation ( $\mathrm{kao}$ ) of categories; venerating [heaven's] seasons/time through the initiation of affairs (agriculture and sacrifice); venerating [heaven's] source through the reading (zhan) of things past; and venerating [heaven's] course through the knowledge of things to come.

大業載之, 吉凶生焉, 是以君子將有興焉, 咨焉而以從事, 受命 而莫之違也。若夫用天因地, 揆時施教, 頒諸明堂, 以為民極者,

\footnotetext{
${ }^{4}$ Yan Shigu (581-645 CE) explains that "the "great method in nine chapters" is the nine divisions of the "Great Plan" (Hong fan), the fourth of which is the coordination of the "five regulators" ' (HS 21A.973 (comm.)). Preserved in the Book of Documents, the 'Hong fan' is the manifesto for good governance that Jizi, a virtuous minister of the Yin-Shang, supposedly passed to King Wu upon his founding of the Zhou. The 'Hong fan' identifies the 'five regulators' thus: 'the first is the agricultural year (sui); the second is the moon; the third is the sun; the fourth is the stars; and the fifth is the li numbers' (Shangshu zhushu, 12.171b). On the term ji 'regulator', see Section 1.1.3 below.

${ }^{5}$ The 'six ancient $l i$ ' are those supposedly implemented by the ruling clans of the Three Dynasties and their bloodlines in the dukedoms, marquisates and kingdoms of the subsequent period of disunion (770-221 BCE). The Yellow Emperor's $l i$ activities are clearly legendary, but the other 'ancient $l i$ ' are serious historical questions explored in Hirase (1996) and Gassmann (2002). The 'six ancient li' became a topic of scholarly interest as early as the Han, by which time what has survived of them was already considered suspect; see Zhang Peiyu et al. (2008, 251390).
} 
莫大乎月令。帝王之大司備矣, 天下之能事畢矣。過此而往, 摩 忌荷禁，君子未之或知也。

[The sages'] great patrimony has conveyed it [unto us], and blessing and blight are born therefrom - and that is the reason why the true gentleman (junzi) arises therefrom, why [he] takes consultation of it in the pursuance of his affairs and why [he] would rather accept his fate than violate it. Now, for the sake of keeping to heaven and conforming to earth, surveying ( $k u i)$ the seasons/time and spreading the teachings, promulgating [li] at the Bright Hall and acting as the pole [star] of the people - [for this] there is nothing greater than the monthly ordinances (yue ling). When [this] the great affair of the god king is complete, [his] special capacity towards the world-under-heaven is replete. Beyond this, nothing of the teeming taboos and negligent prohibitions (hemerology) does the true gentleman know.

\section{Zhonglun 中論, 2.14a-b:}

昔者聖王之造㦄數也, 察紀律之行, 觀運機之動, 原星辰之迭中, 㝥崇景之長短, 於是營儀以准之, 立表以測之, 下漏以考之, 布 算以追之; 然後元首齊乎上, 中朔正乎下, 寒暑順序, 四時不忒。 夫㦄數者, 先王以憲殺生之期, 而詔作事之節也, 使萬國之民不 失其業者也。

As to the sage kings' creation (zao) of $l i$ numbers in the past, [they] inspected (cha) the operation of regulators and pitch pipes (ji lï), observed (guan) the movement of the 'rotating mechanism' (yun ji), plumbed the consecutive culminations of the stars, and apprehended the varying lengths, of light and shadow. Thereupon, they constructed instruments to level them, erected gnomons to measure (ce) them, set water clocks to investigate ( $\mathrm{kao}$ ) them and spread out counting rods to catch them. Thereafter, the origin and [era] heads were aligned [in the past] above, and the medial [qi] and new moons were straightened [in the present] below; cold and hot proceeded in proper order, and the four seasons did not err. ${ }^{6}$ Now, li numbers are the means by which former kings announced the periods of taking life and ordered the rhythms of the initiation of affairs - that which ensures that the people of the myriad states are not remiss in their patrimonies.

\section{Shangshu zhushu 尚書注疏, 4.56a (subcommentary):}

天之歷運之數帝位

$\ldots$ the number(s) $(s h u)$ of imperial ascension as sequentially revolved through (li yun) by heaven.

Shiji 史記, 1.16:

數法日月星辰

... to number $(s h u)$ and model $(f a)$ the sun, moon and stars.

Shangshu zhushu 尚書注疏, 12.171b (subcommentary):

㷴數, 等日月行道所歷計氣朔早晚之數, 所以為一歲之㷴。

\footnotetext{
${ }^{6}$ In Han terms, an 'origin' (yuan) is the period it takes for all $l i$ cycles to coincide anew; a 'head' (shou) denotes the beginning of a lesser period, like an 'era' (ji), in which everything but the sexagenary day-count coincides; 'medial qi' (zhong qi) are twelve equal divisions of the solar year, counted from winter solstice, which later intercalation practices link to specific months or 'new moons' of the calendar year. For the twelve medial qi, see Table 1.1 and Appendix, Figure 2, below.
} 
' $L i$ numbers': the numbers of the timing of the $l i$-accounted $q i$ and new moons that come from the calculation (suan) of the sun and moon's travel of their paths - that which goes into the $l i$ of one year.

Han shu 漢書, 21A.975:

不能爲算

...couldn't do the maths.

Han shu 漢書, 21A.975:

民間治曆者

...li handlers from among the folk.

Han shu 漢書, 21A.976

尤疏遠

...particularly loose $(s h u)$ and far off (yuan).

Han shu 漢書, 21A.978

陰陽不調

...maladjustment of yin-yang.

Han shu 漢書, 21A.978:

太初曆第一, 郎墨徐萬且、長安徐禹治太初曆亦第一

The Grand Inception $l i$ was number one; the Grand Inception $l i$ made by Xu Wanju of Jimo and Xu Yu of Chang'an was also number one.

Han shu 漢書, 21A.979:

說春秋

...to explain the Spring and Autumn Annals.

Han shu 漢書, 12.351:

班教化，禁淫祀，放鄭聲

...promulgate indoctrination, prohibit excessive sacrifices and banish [lascivious music].

Hou Han shu 後漢書, zhi 2, 3025:

盛等所中多岑六事

... Sheng et al. bull's-eyed (zhong) six more items than Cen.

Hou Han shu 後漢書, zhi 2, 3026:

三百年斗曆改憲

...every three hundred years the Dipper $l i$ must be reformed.

Hou Han shu 後漢書, zhi 2, 3027:

復發聖思

...re-evaluated [his] sage thoughts.

Hou Han shu 後漢書, zhi 2, 3027: 
無文正驗

...validating experience without text[ual precedent].

Hou Han shu 後漢書, zhi 2, 3029:

日無前却，弦望不差一日，比用赤道密近，宜施用

...the sun falls neither ahead nor behind, nor do quarter and full moons err by one day; it is tighter and closer than using the red road and [thus] suitable for [official] implementation.

Hou Han shu 後漢書, zhi 2, 3030:

月所行道有遠近出入...九歲九道一復

...the path(s) travelled by the moon has far and near, egress and ingress', the 'speedy place' ( $j i \mathrm{chu}$, i.e. perigee) precessing at a rate of three $d u$ per month such that 'the nine roads return/repeat once every nine solar years.

Hou Han shu 後漢書, zhi 2, 3027:

令史官以九道法候弦望, 驗無有差跌

...watch [the lunar phases] via the nine-roads method, [and they] verified that there was no misstep [between them].

Hou Han shu 後漢書, zhi 2, 3030:

少循其事... 廢而不修

... rarely heeded... abandoned and no longer studied.

Hou Han shu 後漢書, zhi 2, 3034:

參案儀注, 考往校今, 以為九道法最密

...having investigated (kao) the past and analysed (jiao) the present by way of reference to instrument [observational] notes (yi zhu), [we] consider the nine-road method the most tight (mi).

Hou Han shu 後漢書, zhi 2, 3034:

用九道為朔, 月有比三大二小

...using the nine roads for new moons, the [civil] month would see three bigs and two smalls in a row.

Hou Han shu 後漢書, zhi 2, 3033:

此二家常挾其術

these two schools forever cleaving to their [respective] procedures.

Hou Han shu 後漢書, zhi 3, 3082:

鱼能著文...洪能為等

Yong could compose text ... and Hong could do the calculations.

Jin shu 晉書, 17.499

潛精內思二十餘載

...absorbing [himself] in inner contemplation for more than twenty years. 
Sanguo zhi 三國志, 47.1129:

二年春正月...改四分，用乾象曆

...in [Yellow Militarism] 2-I (223 CE) ... the Quarter-remainder was reformed (gai) and the Supernal Icon $l i$ was used (yong).

Jin shu 晉書, 17.498:

其為之也, 依易立數, 遁行相號, 潛處相求, 名為乾象曆。又創 制日行遲速，兼考月行，陰陽交錯於黃道表裏，日行黃道，於赤 道宿度復有進退。方於前法, 轉為精密矣。

What [Liu Hong] did was establish numbers $(s h u)$ based on the [Book of] Changes [such that] they called out to one another in hidden motion and sought each other out from secret parts - and [at this he] named it the 'Supernal Icon li'. Also, [he] created (chuangzhi) the solar/daily motion slow-fast (i.e. equation of centre) while concurrently investigating ( $\mathrm{kao}$ ) lunar motion, [concluding that] yin and yang (i.e. negative and positive latitude) cross inside an outside the yellow road, and that the sun travels on the yellow road, experiencing advance and retreat in terms of red-road lodge $d u$ (i.e. a reduction to the equator) - and only with this was there a turn (zhuan) towards the fine and tight (jing $\mathrm{mi}$ ) relative to prior methods $(\mathrm{fa})$.

Hou Han shu 後漢書, zhi 25, 3572:

掌天時、星曆。凡歲將終, 奏新年曆。凡國祭祀、喪、娶之事, 掌奏良日及時節禁忌。凡國有瑞應、災異, 掌記之。

[The Prefect Grand Clerk] handles the seasons/time of heaven and sequence of the stars (xing li). Near the end of each year, [he] memorialises the new year's $l i$ (civil calendar). For all state matters of sacrifices, funerals and weddings, he handles the memorialising of auspicious dates and seasonal prohibitions. For every time that the state experiences an auspicious [omen-]response (ying) or calamitous anomaly, [he] handles the recording of it.

Hou Han shu 後漢書, 45.1519:

策由眾定。

...policy is settled in accordance with the many.

Han shu 漢書, 36.1963:

夜觀星宿, 或不棩達旦

...nightly observing stars and lodges [he] sometimes didn't sleep until the break of dawn.

Sanguo zhi 三國志, 42.1020:

於庭中作小樓, 家富多奴, 常令奴更直於樓上視天災。

...constructed a small tower at the centre of his courtyard, and as his family was rich, with many slaves $(n u)$, [he] regularly ordered slaves to take shifts atop the tower to watch for heavenly [phenomena].

Sui shu 隋書, 20.561:

隱於海島中，積三十許年，專以渾儀測候日月五星差變之數 ... went into hiding on a sea isle where he devoted himself for more than thirty years to the observation, by means of [armillary] sphere 
instrument, of data on the differences and changes in the sun, moon and five [planets].

Shiji 史記, 27.1349-50:

故甘、石曆五星法, 唯獨熒惑有反逆行; 逆行所守, 及他星逆行, 日月薄蝕, 皆以為占。…余觀史記, 考行事, 百年之中, 五星無 出而不反逆行, 反逆行, 嘗盛大而變色…此其大度也。

In the old Gan [De] and Shi [Shen] methods for li-computing the five [planets] only [Mars] had retrogradation. They took the [asterisms] it guards in retrograde, the retrogradation of other [planets], and the veilings and eclipses of sun and moon all as [objects of] omen interpretation (zhan) ... I have observed (guan) the clerk's records (shiji) and examined ( $\mathrm{kao}$ ) past events, and in a hundred years the five [planets] have never once emerged without going into retrograde ... this is their great measure.

Hou Han shu 後漢書, zhi 2, 3026:

先立春一日, 則四分數之立春也, 而以折獄斷大刑, 於氣已迕, 用望平和，蓋亦遠矣。

The Quarter-remainder reckons the establishment of spring. ${ }_{\mathrm{Q} 01}$ to fall

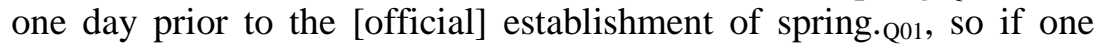
were to open prisons and end great punishments by [the latter], one would violate the $q i$ (cosmic energies) and distance oneself from any prospect of peace or harmony.

Hou Han shu 後漢書, zhi 2, 3041:

以是言之, 則術不差不改, 不驗不用。天道精微, 度數難定, 術 法多端, 曆紀非一, 未驗無以知其是, 未差無以知其失。失然後 改之, 是然後用之, 此謂允執其中。

For procedures (shu), one doesn't revise (gai) what isn't in error (cha), and one doesn't use what isn't verified (yan). The way of heaven is perfect and subtle, its $d u$ and numbers being hard to fix; there is a variety of procedures and methods, the net threads of $l i$ ( $l i j i$ ) being not [just] one. Without verification (yan), there is no way to know that it is correct (shi); without erring (cha), there is no way to know that it is amiss (shi). If it is amiss (shi), you then revise (gai) it; if it is correct (shi), you then use it - this is called 'holding truly to the middle way' (citing Analects XX.1).

Hou Han shu 後漢書, zhi 2, 3026:

他元雖不明於圖驖，各自一家之術，皆當有效於當時

...though alternative origin [dates] may not be elaborated in the charts and prophecies, each [has fostered] the procedures of its own expert lineage (jia) and thus must have had validity (xiao) in its own time.

Hou Han shu 後漢書, zhi 2, 3043:

雖有師法, 與無同

...though [he] has a master's method, it is the same as if he had none at all. ${ }^{8}$

\footnotetext{
${ }^{7}$ Tr. modified from Cullen (2007a, 241).

${ }^{8}$ Tr. modified from Cullen (2007a, 247, 259).
} 
Hou Han shu 後漢書, zhi 2, 3030:

永平中, 詔書令故太史待詔張隆以四分法署弦、望、月食加時。 隆言能用易九、六、七、八爻知月行多少。今案隆所署多失。臣 使隆逆推前手所署, 不應, 或異日, 不中天乃益遠, 至十餘度。

During the Eternal Tranquillity reign $(57-75 \mathrm{CE})$, there was an edict ordering Zhang Long, former expectant appointee to the Grand Clerk, to (predictively) note the added hour of [lunar phases] and lunar eclipse according to the Quarter-remainder method. Long said that he was able to use the nine, six, seven and eight lines from the Changes to know the extent of lunar motion. ${ }^{9}$ [We] now know Long's notes to have missed the mark (shi) in most cases. [I,] Your servant, made Long retrodict [added hours] noted by former hands, and they did not correspond, sometimes [even] falling on different days; he was even further off (yuan) in failing to hit the mark (zhong) in heaven, [being off by a matter of] up to more than ten $d u$.

9 On the Changes hexagram line numbers 'nine, six, seven and eight', see Rutt (1996, 151-201). 


\section{Chapter 2}

Shangshu zhushu 尚書注疏, xx:

欽若昊天

...in reverent accordance with prodigious heaven.

Yuan shi 元史, 164.3850:

私意牽就

... yielding to personal inclination.

Song shu 宋書, 12.262:

檢十一年七月十六日望月蝕, 加時在卯, 到十五日四更二唱丑初 始蝕, 到四唱蝕既, 在營室十五度末。景初其日日在軫三度。以 月蝕所衝考之, 其日日應在翼十五度半。

It was inspected (jian) that at full moon, 11-VI-16, the moon was eclipsed. The added hour (jia shi) was mao. The eclipse began on day 15 in the second chant of the fourth watch, at the beginning of chou, and the eclipse was complete in the fourth chant, at the end of Hall $15 d u$. The Luminous Inception had the sun at Baseboard $3 d u$ that day. Examining $(\mathrm{kao})$ it by means of opposition to the place of lunar eclipse, the sun should have been at Wings $15 d u$ and a half that day.

Sui shu 隋書, 19.526:

昔黃帝創觀漏水, 制器取則, 以分書夜。其後因以命官, 周禮垭 壼氏則其職也

... the Yellow Emperor invented (chuang) the observation (guan) of leaking water and fabricated a/the vessel upon the principle with which to divide the day and night.

Chuxue ji 初學記, 25.1a:

漏刻之作蓋肇於軒轅之日

The rise of the leak-notch began in the days of Xuanyuan.

Chuxue ji 初學記, 25.2a:

以銅為器, 再疊差置, 實以清水, 下各開孔, 以玉虬吐漏水入兩 壼, 右為夜, 左為書。

The vessels are made of bronze; they are placed one above the other at different levels and filled with pure water. Each opens at the bottom in a hole, where jade dragon baby [spouts] spit leak water into two jars right for night and left for day.

Wenxuan zhu 文選注, 56.25a (commentary):

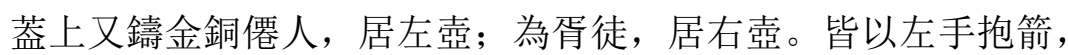
右手指刻, 以别天時早晚。

On the lids (of each inflow receiver) are furthermore cast in gilt bronze an immortal, dwelling on the left jar, and an attendant for [his] assistance, dwelling on the right jar. Both [statuettes] hold an arrow 
with the left hand and indicate the notch [with] the right hand so as to distinguish [what is] early and late by heaven's time. ${ }^{10}$

Taiping yulan 太平御覽, 2.13b:

累筒三階

... stacked vessels in three tiers.

Zhouli zhushu 周禮注疏, 30.461b:

及冬則以火䀢鼎水

... heat a cauldron of water with fire in the winter.

Chuxue ji 初學記, 25.2b; Taiping yulan 太平御覽, 2.13a:

余為郎, 典漏刻, 燥濕寒温輙異度, 書日系以㫡景, 暮夜养以星 宿, 則得其正。

As a gentleman-of-the-palace, I was in charge of the leak notch. The $d u$ would differ as soon as it was dry or humid, cold or warm, but one was able to right (zheng) it if checked (can) by day against the gnomon shadow and checked (can) by night against the stellar lodges.

Sui shu 隋書, 19.526:

總以百刻, 分于書夜。冬至書漏四十刻, 夜漏六十刻。夏至書漏 六十刻, 夜漏四十刻。春秋二分, 書夜各五十刻。日未出前二刻 半而明, 既沒後二刻半乃昏。減夜五刻, 以益書漏, 謂之昏旦。 漏刻皆隨氣增損。冬夏二至之間, 書夜長短, 凡差二十刻。每差 一刻為一箭。冬至互起其首, 凡有四十一箭。

A total of 100 notches were split between day and night, with 40 day notches to 60 night notches at winter solstice, 60 day notches to 40 night notches at summer solstice, and 50 day notches to 50 night notches at the spring and autumn equinoxes. It is bright two notches and a half before the sun has risen, and it is dark two notches and a half after it has completely set, so five notches are subtracted from the night and added to the day leak [pot] - we refer to this as 'dusk' and 'dawn'. Both drip notches increase and decrease in accordance with the [twenty-four] qi. Between winter and summer solstice there is a total difference between the length of day and night of 20 notches, for each difference of one notch there being a new arrow [pair]. Starting in both directions from winter solstice, there is a total of 41 [changes of] arrow [pairs].

Hou Han shu 後漢書, zhi 2, 3033:

官漏失天者至三刻...少所違失, 密近有驗

... the official drip missed the mark (shi) of heaven in upwards of three notches... reduces the disparity, [and its] tightness and closeness have been verified.

Zhoubi suanjing 周骿算經, $1.1 \mathrm{~b}$ :

古者包犧立周天曆度

$\ldots$ in antiquity [Fu]xi established the $l i d u$ (successive/astronomical degrees) of the circuits of heaven.

${ }^{10}$ Cf. Needham $(1959,320)$. 
Sui shu 隋書, 19.523:

昔者周公測崇影於陽城，以參考曆紀

... long ago, the Duke of Zhou measured gnomon shadows at Yangcheng so as to investigate (can-kao) the net threads (ji) of $l i$.

Zhoubi suanjing 周髀算經, $1.26 \mathrm{a}, 37 \mathrm{~b}$ :

周髀長八尺

The Zhou gnomon was eight chi long $(184.8 \mathrm{~cm})$.

Sui shu 隋書, 19.523:

取平正

...getting it level and upright.

Hou Han shu 後漢書, zhi 3, 3057:

曆數之生也, 乃立儀表, 以校日景。景長則日遠, 天度之端也。 日發其端, 周而為歲, 然其景不復, 四周千四百六十一日, 而景 復初, 是則日行之終。以周除日, 得三百六十五四分度之一, 為 歲之日數。日日行一度, 亦為天度。

In the derivation of $l i$ numbers, one sets up the sight (?) and gnomon to compare (jiao) solar shadows. When the [noon] shadow is longest then the sun is most distant: this is the starting point of the $d u$ of heaven [i.e. the winter solstice]. The sun leaves its starting point, and makes a circuit in a year, but the [noon] shadow does not repeat. After four circuits, i.e. 1,461 days, the shadow repeats its starting [value], and this is the conclusion of the [whole pattern of] the sun's movement. If you divide the days by the circuits, you get 365 and $1 / 4 d u$, which is the number of days in a solar year (sui). The sun moves one $d u$ in a day, so this is also [counted in] the number of $d u$ in [one circuit of] heaven (for a diurnal rotation of $366^{1 / 4} d u$ ). ${ }^{11}$

Song shi 宋史, 76.1763:

晉、漢曆術, 多以前後所測晏要取其中，此亦差過半日

the $l i$ procedures of the Jin and Han mostly took middle [values] between gnomon measurements before and after [the solstice] - this, for its part, exceeded half a day (ri) in error.

Zhoubi suanjing 周髀算經, 2.22b:

凡八節二十四氣，氣損益九寸九分六分分之一

[over] all the eight nodes and twenty-four $q i$, [the gnomon shadow] is reduced/increased by 99 fen and $1 / 6$ fen per $q i$.

Han shu 漢書, 21A.975:

乃定東西，立㫡儀，下漏刻，以追二十八宿相距於四方，舉終以 定朔晦分至、䠎離弦望。

[They] fixed east and west, erected gnomon and sight, and dropped the leak notch in pursuit of the distances between the twenty-eight lodges of the four quadrants (of the sky) and, in the end, to fix the new and dark moons (first and last days of the month), the equinoxes and solstices, and the steps and distances of quarter and full moons.

${ }^{11}$ Tr. modified from Cullen $(1996,96)$. 
Hou Han shu 後漢書, zhi 3, 3056:

下漏數刻，以考中星

... dropping the leak and counting the notch to examine the centred stars.

Sui shu 隋書, 19.521:

影漏去極, 就渾可推, 百骸共體, 本非異物。此真已驗, 彼偽自 彰, 豈朗日未暉, 爝火不息, 理有而䦕, 詎不可悲者也?

Shadow, leak and polar distance can [all] be extrapolated (tui) from the sphere, their being not different things but the hundred bones of a common body. The truth (zhen) of this is already verified (yan), and the falsehood (wei) of that is self-evident, [so] how is it that the bright sun (of truth) has yet to shine and that the torchlight (of benightedness) [burns] unextinguished - that the reasoning (li) is there and yet left to ruin? Is not this grievous?

Sui shu 隋書, 19.521:

焯今立術, 改正舊渾... 又以二至之影, 定去極㟯漏, 并天地高遠, 星辰運周, 所宗有本, 皆有其率。

... established a procedure to reform and correct the old sphere... the [gnomon] shadows of the two solstices.

Sui shu 隋書, 19.521-2:

張衡、鄭玄、王蕃、陸績先儒等, 皆以為影千里差一寸。言南戴 日下萬五千里, 表影正同, 天高乃異。考之算法, 必為不可。寸 差千里, 亦無典說, 明為意斷, 事不可依。今交、愛之州, 表北 無影, 計無萬里, 南過戴日。是千里一寸, 非其實差。

Previous scholars like Zhang Heng, Zheng Xuan (127-200 CE), Wang Fan (228-66 CE) and Lu Ji (188-219 CE) all took it [for granted] that the shadow differs by one cun for a thousand $l i$. [They all] say that the sub-solar point in the south (the Tropic of Cancer) is 15,000 li $(6,885 \mathrm{~km})$ [from Luoyang], [but though] the gnomon shadow [at Luoyang that they used to derive this figure] is exactly the same, the [figures for] the height for heaven [at which they arrive] are somehow different! Investigate ( $k a o$ ) it via computational methods (suan fa), and [one will see that] this is certainly unacceptable. That a cun difference [corresponds to] a thousand $l i$ is likewise devoid of canonical explanation (precedent) - [this] is clearly an arbitrary supposition (yiduan) which cannot be taken for granted. Now, in Jiao[zhou] and Aizhou (modern Vietnam), there is no shadow north of the gnomon [at summer solstice], [by which we can] estimate that in less than $10,000 \mathrm{li}(4,590 \mathrm{~km})$ one goes south past the sub-solar point. This is [proof that] a thousand $l i$ per cun is not the true (shi) difference.

Sui shu 隋書, 19.520:

昔者聖王正曆明時, 作圓蓋以圖列宿。極在其中, 廻之以觀天象。 分三百六十五度、四分度之一, 以定日數。...今案自開皇已後, 天下一統, 靈臺以後魏鐵渾天儀, 測七曜盈縮, 以蓋圖列星坐, 分黃赤二道距二十八宿分度，而莫有更為渾象者矣。

In the past, when the sage kings corrected the $l i$ and elucidated time, they created a round umbrella to diagram the array of lodges. The pole was at its centre, and one rotated (hui) it in order to observe (guan) the heavenly signs. It was divided into $365 d u$ and $1 / 4 d u$ so as to fix the 
number of days (in a year) ... Here I note that after the Opening Sovereignty era $(581-600 \mathrm{CE})$, the world under heaven was unified, and the Numinous Terrace (observatory) used the [Tuoba] Wei (386$535 \mathrm{CE}$ ) iron sphere heaven sights (huntian yi) to measure the excess and deficit of the seven luminaries, and [they] used a/the umbrella diagram to array the star seats (constellations) and divide the $d u$ fractions of the distance of both the yellow and red roads (ecliptic and equator) from the twenty-eight lodges - no one ever made the switch to the sphere effigy (hun xiang) [for this task]!

Sui shu 隋書, 19.504-5:

乃命属季才等, 參校周、齊、梁、陳及祖晅、孫僧化官私舊圖, 刊其大小，正彼疎密，依準三家星位，以為蓋圖。旁摛始分，甄 表常度, 并具赤黃二道, 內外兩規。懸象著明, 緾離做次, 星之 隱顯, 天漢昭回, 宛若穹蒼, 將為正範。

Yu Jicai (d. $603 \mathrm{CE}$ ) et al. were ordered to reference (can) and compare (jiao) the old diagrams, official and private, of the [previous dynasties] and of $\mathrm{Zu}$ Geng and Sun Senghua (d. 538/539 CE), to cut their sizes, correct their looseness/tightness, and to create an umbrella diagram on the basis of the Three Experts' star positions. ${ }^{12}$ Laterally, it spread the starting divisions; discriminatingly, it indicated the constant $d u$, and it was possessed of both red and yellow roads in two compass [circles], inside and out. The suspended signs, manifest and brilliant, the circling divisions, spacious and sequenced, the obscurity and plainness of the stars, the luminous curve of the Heavenly Han (the Milky Way) - bent like the vaulted grey (the sky), it would become the orthodox model.

Hou Han shu 後漢書, zhi 2, 3029:

度日月行，考驗天運狀...比用赤道密近

$\ldots d u$-measure solar and lunar motion, and investigate (kao) and verify (yan) the manner of heaven's revolution... tighter and closer than using the red road.

Hou Han shu 後漢書, zhi 2, 3037:

曆度審正，圖儀炙漏。

... diagram sight, gnomon and leak [notch]... examination and correction of the $l i d u$.

Hou Han shu 後漢書, zhi 2, 3039:

以今渾天圖儀檢天文

... the use of the sphere heaven [and] diagram sight to examine (jian) tianwen.

Sui shu 隋書, 19.517:

渾天儀者, 其制有機有衡。既動靜兼狀, 以效二儀之情, 又周旋 衡管, 用考三光之分。所以揆正宿度, 準步盈虛, 來古之遺法也。 The sphere heaven sight is constructed with engine and traverse. Not only in its at once moving and static state does it replicate the true

\footnotetext{
${ }^{12}$ The 'Three Experts' (san jia) of 'star canon' catalogue literature refer to the likely apocryphal pre-imperial figures of Shi Shen, Gan De and Wuxian, on which see Sun \& Kistemaker (1997).
} 
situation (qing) of the two yi (yin and yang), the complete rotation of the transverse tube allows investigation of the fractions of the three lights (the sun, moon and stars). It is that by which one estimates and corrects the lodge $d u$ and levels and paces excess and void - a method handed down from antiquity.

Sui shu 隋書, 19.519:

渾天象者, 其制有機而無衡... 不如渾儀, 別有衡管, 測揆日月, 分步星度者也。

The sphere heaven effigy is constructed with engine and no traverse... It is inferior to the sphere sight, which has in addition a traverse tube the thing that [allows] the measure and estimation of sun and moon and the division and pacing of stars and $d u$.

Shangshu zhushu 尚書注疏, 3.35b:

在瓐璣玉衡以齊七政

... attended to the xuanji yuheng so as to order the seven governors/government matters.

Wen yao gou 文曜鉤, cited in Jin shu 晉書, 11.284:

唐堯即位, 羲和立渾儀

... when Yao of Tang took the throne, the $\mathrm{Xi}$ and $\mathrm{He}$ [brothers] established the sphere sight.

Sui shu 隋書, 19.515-16:

馬季長創謂璣衡為渾天儀

It was Ma Jichang (i.e. Ma Rong, 79-166 ce) who first conceived of saying that the [xuanji] yuheng was the sphere heaven sight.

Sui shu 隋書, 19.516-17:

至桓帝延喜七年, 太史令張衡, 更以銅製, 以四分為一度, 周天 二丈四尺六寸一分。亦於密室中, 以漏水轉之。令司之者, 閉戶 而唱之, 以告靈臺之觀天者, 姃璣所加, 某星始見, 某星已中, 某星今沒，皆如合符。

In Emperor Huan, Prolongation of Brightness 7 (164 CE), Prefect Grand Clerk Zhang Heng redesigned [the $103 \mathrm{CE}$ 'bronze sight'] in bronze with four fen $(9.4 \mathrm{~mm})$ to the $d u$, for a circuits of heaven of $1^{\mathrm{z}} 4^{\mathrm{ch}} 6^{\mathrm{c}} 1^{\mathrm{f}}(343.34 \mathrm{~cm})$. It was placed in a sealed-tight $(\mathrm{mi})$ chamber and rotated by means of leak (water clock) water. The person charged with watching called it out from behind closed doors to announce to the observers of heaven (guan tian zhe) of the Numinous Terrace (observatory) the add[ed hour] (?) of the xuanji, that such-and-such star was first visible, that such-and-such star was already centred (culminated), and that such-and-such star was currently setting - all of which were like matching [the two halves of] a tally.

Huntian yi 渾天儀, cited in Hou Han shu 後漢書, zhi 3, 3076 (comm.):

上頭橫行第一行者, 黃道進退之數也。本當以銅儀日月度之, 則 可知也。以儀一歲乃竟, 而中閒又有陰雨, 難卒成也。

The first row running horizontally up on top are the numbers of yellow-road advance-retreat. What one should do is $d u$-measure these 
over days and months via a/the bronze sight - then could [they] be known - [but as] this would take a year at the sight to complete, and [as] there would furthermore be overcast and rainy [days] interspersed therein, it would be difficult to bring to successful completion.

Huntian yi 渾天儀, cited in Hou Han shu 後漢書, zhi 3, 3076 (comm.):

是以作小渾，盡赤道黃道，乃各調賦三百六十五度四分之一，從 冬至所在始起, 令之相當值也

... make a small sphere complete with red road and yellow roadpath, then allocate (graduate) each with $365 d u$ and $1 / 4 d u$ and make sure to align their relative values starting from the position of winter solstice.Q22'.

Huntian yi 渾天儀, cited in Hou Han shu 後漢書, zhi 3, 3076 (comm.):

為〔百〕八十二度八分之五

... make $182 d u$ and $5 / 8[d u]$.

Sui shu 隋書, 19.519:

其圓如丸, 其大數圍。南北兩頭有軸。徧體布二十八宿、三家星、 黃赤二道及天漢等

... round like a pellet, several spans large, with axes at the north and south heads, and its entire body laid out with the twenty-eight lodges, the Three Expert [catalogue] stars, the yellow and red road, as well as the Heavenly Han, etc.

Sui shu 隋書, 19.519:

五分為一度，徑六尺八分少，周一丈八尺二寸六分少

.. 5 fen $(12.35 \mathrm{~mm})$ per $d u$ for a diameter of $6^{\text {ch }}{ }^{\text {c }} 8^{\mathrm{f}}$ and less $(150.24 \mathrm{~cm})$ and a circuit of $1^{\mathrm{z}} 8^{\mathrm{ch}} 2^{\mathrm{c}} 6^{\mathrm{f}}$ and less $(451.08 \mathrm{~cm})$.

Sui shu 隋書, 19.520:

二分為一度，徑二尺二寸，周六尺六寸 ...而地在其中

.. 2 fen $(4.94 \mathrm{~mm})$ per $d u$ for a diameter of $2^{\mathrm{ch}} 2^{\mathrm{c}}(54.34 \mathrm{~cm})$ and a circuit of $6^{\text {ch }} 6^{\mathrm{c}}(163.02 \mathrm{~cm}) \ldots$ and the earth was at its centre.

Sui shu 隋書, 19.519:

地在天內, 不動。立黃赤二道之規, 南北二極之規, 布列二十八 宿、北斗極星

... earth was inside heaven, unmoving, and he established rings (gui) for the yellow and red road and rings for the north and south poles, upon which were arrayed the twenty-eight lodges and Northern Dipper and pole star.

Sui shu 隋書, 19.519:

至如斯制, 以為渾儀, 儀則內關衡管。以為渾象, 而地不在外。 是參兩法, 別為一體。就器用而求, 猶渾象之流。

As to this construction, it could be taken for a sphere sight, but the sight is absent a traverse tube inside; it could be taken for a sphere effigy, but the earth is not on the outside [see Figure 2.5]. This 
references both models $(f a)$ but constitutes a separate form ( $t i)$. Gathering from the device's use, it would seem to belong to the current (i.e. tradition) of sphere effigies.

Sui shu 隋書, 19.519:

儀象二器, 遠不相涉

... the sight and effigy are two [distinct] devices with nothing whatsoever to do with one another.

Sui shu 隋書, 19.516:

地中轉渾天

... turned a/the sphere heaven in/at the centre of the earth.

Yangzi fayan 揚子法言, $10.1 \mathrm{~b}$ :

落下閏營之

... Luoxia Hong ying-ed it.

Xin lun 新論; cited in Taiping yulan, 2.11a-b:

桓子新論曰：揚子雲好天文，問之於黄門作渾天老工，曰：「我 少能作其事, 但隨尺寸法度, 殊不曉達其意。我稍稍益愈, 到今 七十, 乃甫適知己, 又老且死矣。今我兒子受學作之, 亦當復年 如我, 乃曉知己，又且復死焉。」其言可悲可笑也。

Yang Ziyun (Yang Xiong) was fond of tianwen, and he asked about it from the old Yellow Gate (palace) artisan who made sphere heaven(s), [who] said, 'I was able to make the thing when I was young, [but I] was merely following the stipulated chi and cun (dimensions) [that I was handed] without really understanding what they meant. Little by little, I gradually got better [at it], but now [I am] seventy, old and about to die by the time that $[\mathrm{I}]$ have only begun to understand myself. Now my son receives training [on how to] make it, and [he] too shall repeat the years like me, being old and about to die by the time [he] understands himself'.

Hou Han shu 後漢書, zhi 2, 3029-30:

以角為十三度, 六十...凡三百六十五度四分度之一。冬至日在斗 十九度四分度之一。史官以郭日月行, 參弦望, 雖密近而不為注 日。儀, 黃道與度轉運, 難以候, 是以少循其事。

With Horn.L01 as $13 d u$, Neck.L02 [as] $10 \ldots$ for a total of $365 d u$ and $1 / 4 d u$. The winter solstice was at Dipper.L08 $19 d u$ and $1 / 4 d u$. The Clerk's Office perimetered (?) solar and lunar motion and checked quarter and full moons, and though it was tight and close, it was not used for noting the sun/days. As to the sights (yi), the yellow road and $d u$ (equator ring) rotated, [but it] was difficult to watch (hou) [with], which is why the matter (the order to use it) was rarely heeded.

Sui shu 隋書, 19.517-18:

有雙規相並...周币分為度數, 署以維辰之位

... double ring-circles joined [parallel] to one another with roughly three cun $(9.09 \mathrm{~cm})$ between them... divided around the circumference into $d u$ numbers and inscribed with the positions of the corners and chronograms'. 
Sui shu 隋書, 19.517-18:

其雙軸之間, 則置衡, 長八尺, 通中有孔, 圓徑一寸

... double circles joined [parallel] to one another... a traverse eight $c h i$ $(242.4 \mathrm{~cm})$ in length, through the centre of which was a [sighting] hole one cun $(3.03 \mathrm{~cm})$ in diameter.

Jiu Tang shu 舊唐書, 79.2718:

經緯三百六十五度

... $365 d u$ in warp (RA) and weft (declination).

Jiu Tang shu 舊唐書, 35.1297-8:

極畫兩方，東西列周天度數，南北列百刻，使見日知時，不有差 謬。上列三百六十策, 與用卦相準, 度穿一穴, 與赤道相交

... extremes (solstices) drawn in two places... the $d u$-numbers of the circuits of heaven ... the 100 notches ... and the 360 rods, levelled with the reigning hexagrams.

Sui shu 隋書, 19.518:

其餘皆與劉曜儀大同

... everything else was largely the same as [Xiongnu Emperor] Liu Yao [of Zhao's] sight.

Sui shu 隋書, 19.505:

史臣於觀臺訪 渾儀, 見元魏太史令泉崇所造者, 以鐵為之

[I, His Majesty's] historian/clerk servant went to the observation terrace to visit the sphere sight and saw (jian) that it was the original constructed by [Tuoba] Wei Prefect Grand Clerk Chao Chong and that it was made of iron.

Sui shu 隋書, 19.518:

檢其鑴題，是偽劉曜光初六年，史官丞南陽孔挺所造

Inspection (jian) of the engraving [reveals that] it was constructed by Clerk's Office Assistant Kong Ting of Nanyang in year 6 of the [Xiongnu] imposter Liu Yao's Glory Inception reign $(323 \mathrm{CE})$.

Sui shu 隋書, 17.518:

其於揆測, 唯所欲為之者也

... with regard to observation (kui) and measurement (ce), it did truly everything that one could desire.

Shen Gua 沈括 (1031-95), cited in Song shi 宋史, 48.954-5:

度不可見, 其可見者星也。日、月、五星之所由, 有星焉。當度 之畫者凡二十有八, 而謂之舍。舍所以絜度, 度所以生數也。度 在天者也, 為之璣衡, 則度在器。度在器, 則日月五星可摶乎器 中, 而天無所豫也。天無所豫, 則在天者不為難知也。

$D u$ cannot be seen; what can be seen are stars, and the course of the sun, moon and five [planets] is replete with stars. Those [stars] that act as demarcations of $d u$, they are twenty and eight in total, which we call lodges. Lodges are that by which $d u$ are measured out, and $d u$ are that by which numbers are born. $D u$ are in heaven; but make a 
'device-traverse' (sphere sight), and you have $d u$ on an apparatus. If you have $d u$ on an apparatus, then the sun, moon and five [planets] can be modelled (tuan) within the apparatus, and heaven will have no play $(y u)$. And if heaven has not play, then the things in heaven will not be difficult to know.

Jin shu 晉書, 11.280:

皆好奇徇異之說, 非極數談天者也

... all whimsical and fantastical opinions, not people who discussed heaven by plumbing numbers.

Cai Yong 蔡邑 (133-92 CE), cited in Song shu 宋書, 23.673; Jin shu 晉書, 11.278:

論天體者三家，宣夜之學，絕無師法。周髀術數具存，考驗天狀， 多所違失。惟渾天僅得其情, 今史官所用候臺銅儀, 則其法也。 立八尺圓體, 而具天地之形, 以正黃道, 占察發斂, 以行日月, 以步五緯, 精微深妙, 百世不易之道也。官有其器而無本書, 前 志亦閣

The discourse on heaven's form comprises three expert lineages (jia), but the study of expansive night has died out and has no master's method (shifa). Both the procedures and numbers (shu shu) of the Gnomon of Zhou survive, but when examined (kao) and verified (yan) against the case of heaven, there is much that misses the mark. It is only sphere heaven which completely grasps the true circumstances (qing). The observatory bronze sight employed by the Clerk's Office of our day is patterned upon this model $(f a)$ : a sphere erected eight chi [in diameter] and possessed of the forms of heaven and earth by which one aligns the yellow road to observe the release and restrain (of luminary motion), by which one moves the sun and moon, and by which one paces the five [planets] - fine and subtle, profound and mysterious, it is a dao that shall remain unchanged for a hundred generations. The officials have the apparatus but not the original book(s), and the previous monographs are, for their part, faulty... ${ }^{3}$

Cai Yong 蔡邑 (133-92 CE), cited in Song shu 宋書, 23.673:

而不論, 本欲寝伏儀下, 思惟微意, 按度成數, 以著篇章。罪惡 無狀, 投界有北, 灰滅雨絕, 勢路無由。宜問擘臣, 下及巖穴, 知渾天之意者, 使述其義。

... and do not discuss it. [I] had desired originally to lie beneath the sight [to] contemplate its subtleties and master its numbers according to $d u$ in order to write it up into a piece; for [my] inexcusable crime, [however], [I] have been banished to the north to be annihilated by dust and broken by rain, and denied access to any route to influence. It would be appropriate [then] to inquire among [Your] ministers, and down all the way to [hermit] grottoes, about someone knowledgeable on the idea of sphere heaven and order [him] to recount its substance.

Nan shi 南史, 76.1898:

又嘗造渾天象, 高三尺許, 地居中央, 天轉 而地不動, 以機動之, 悉與天相會。云「修道所須, 非止史官是用」。深慕張良為人, 云「古賢無比」

${ }^{13}$ Tr. modified from Ho $(1966,49)$. 
... also once constructed a sphere heaven effigy ... saying 'It is a necessity of practising the dao and not only the Clerk's Office who uses this'.

Sui shu 隋書, 20.561:

至後魏末, 清河張子信, 學㙯博通, 尤精曆數。因避葛榮亂, 隱 於海島中, 積三十許年, 專以渾儀測候日月五星差變之數, 以算 步之, 始悟日月交道, 有表裏遲速, 五星見伏, 有感召向背。

At the end of the [Tuoba] Wei, Zhang Zixin (d. 577 CE) of Qinghe, who was broadly conversant in knowledge and skill, and particularly fine at $l i$ numbers, ensconced himself on a sea isle in order to flee the Ge Rong turmoil (526-8 CE), [and there he] racked up thirty-odd years devoting himself to measuring (ce) and watching (hou) via sphere sight the numbers of the change in the sun, moon and five [planets'] discrepancies (from their mean motions). Pacing them through calculation, [he] first awakened [to the realisation] that the crossed roads of sun and moon see inside and outside (i.e. latitudinal displacement) and retardation and acceleration (i.e. uneven motion), and that the appearance and hiding (i.e. visibility phenomena) of the five [planets] experience stimulus and calling towards and away (i.e. seasonal variation).

Yiwen leiju 藝文類聚, 1.6a-b:

及王府

... to [a] royal palace.

Sui shu 隋書, 17.517:

梁華林重雲殿前所置銅儀

... installed before Double Cloud Hall at [the closed imperial park at] Hualin.

Nan shi 南史, 66.1612:

重雲殿災，安都率將士帶甲入殿，帝甚惡之，自是陰為之備 ... deeply vilified [General] An Du for leading soldiers and wearing armour into the hall [to help], secretly plotting against him from then on.

Sui shu 隋書, 19.518:

皆失之遠矣

... [they] all missed by [a mile].

Sui shu 隋書, 19.505:

新都初成, 以置諸觀臺之上

... upon completion of the new metropolis [in $583 \mathrm{CE}$ ], installed it atop the observation terrace.

Li Chunfeng 李淳風 $(602-70 \mathrm{CE})$, cited in Jiu Tang shu 舊唐 書, 35.1293:

\section{法制疏略}

$\ldots$ its design and construction are loose and rough. 
Yixing 一行 (683-727 CE), cited in Jiu Tang shu 舊唐書, 35.1295:

規制朴略, 度刻不均, 赤道不動, 乃如膠柱, 不置黃道, 進退無 準。此據赤道月行以驗入曆遲速, 多者或至十七度, 少者僅出十 度，不足以上稽天象，敬授人時。

The ring construction is crude and rough, the $d u$ notches are uneven, the red road does not move - being thus like a [stubborn] glued peg (on a moving-peg zither) - and it is not installed with a yellow road there being no guideline for [ecliptic] advance/retreat. This, verifying sequence (li)-entry fast/slow (true speed correction over anomalistic month) based on red-road lunar travel [results in values] too high, sometimes up to seventeen $d u$, and too low, only giving ten $d u$ - this is insufficient to upwardly examine (ji) signs of heaven and reverently grant the seasons of man.

Jiu Tang shu 舊唐書, 35.1293:

其所造渾儀, 太宗令置於凝睴閣以用測候, 既在宮中, 尋而失其 所在。

Taizong ordered the sphere instrument that [Li Chunfeng] had constructed installed in the Pavilion of Congealed Light in order to use it for measuring and watching, and though it was right there in the palace, when [later] looked for, [they] had lost track of where it went.

Xin Tang shu 新唐書, 36.1336:

監司官吏不得更與朝官及諸色人等交通往來，委御史臺察訪

The officers and clerks of the [astronomical] directorate are no longer allowed to communicate or come and go with court officials or any other type of person, the censorate being charged with inspection [of compliance].

Huntian xiang shuo 渾天象說, cited in Song shu 宋書, 23.677:

古舊渾象以二分為一度, 凡周七尺三寸半分。張衡更制, 以四分 為一度, 凡周一丈四尺六寸。蕃以古制局小, 星辰稠概; 衡器傷 大, 難可轉移。更制渾象, 以三分為一度, 凡周天一丈九寸五分 四分分之三也。

Ancient and old sphere effigies took two fen to the $d u$, for a total circuit of $7^{\text {ch }} 3^{\mathrm{c}}$ and a half $f e n(171.67 \mathrm{~cm})$. Zhang Heng's redesign took four fen to the $d u$, for a total circuit of $1^{\mathrm{z}} 4^{\text {ch }} 6^{\mathrm{c}} 1^{\mathrm{f}}(343.34 \mathrm{~cm})$. [I, Wang] Fan find the ancient construction arrangement to be [too] small, the stars being [too] densely packed together; [Zhang] Heng's device, [on the other hand], was painfully large, making it difficult to turn. [I] have [therefore] redesigned the sphere effigy taking three fen to the $d u$, for a total circuits of heaven of $1^{\mathrm{z}}-{ }^{\mathrm{ch}} 9^{\mathrm{c}} 5^{\mathrm{f}}$ and $3 / 4$ fen $(262.98 \mathrm{~cm})$.

He Chengtian 何承天 (370-447 CE), cited in Song shu 宋書, 23.677:

詳尋前說, 因觀渾儀, 研求其意, 有以悟天形正圓, 而水周其下。 The meticulous search of previous explanations [shows that by observing (guan) the sphere sight [they] probed and discovered its meaning, some awakening thereupon to [the fact that] heaven's form is a perfect circle, and that water completely [fills] its bottom [half].

Jingzhou zhan 荊州占, cited in Kaiyuan zhanjing, 30.4b: 
熒惑日行一尺以上，期五月至十五月而廢；五寸以上，期十五月 至二十五月而廢; 三寸以上, 期二十五月至三十月而廢; 一寸以 上，期三十月至五十月廢。諸廢期，月或皆為日。

If [Mars] travels more than one chi (per day?), then in a period of five to fifteen months there is abrogation; more than five cun, then in a period of fifteen to twenty-five months there is abrogation; more than three cun, then in a period of twenty-five to thirty months there is abrogation; more than one cun, then in a period of thirty to fifty months there is abrogation. For the various abrogation periods, the number of months is sometimes given instead as the number of days.

Sui shu 隋書, 31.598:

六年正月己亥, 太白犯熒惑, 相去二寸。占曰:「其野有兵喪, 改立侯王。」

6-I-jihai.36 (3 March 565): [Venus] trespassed upon [Mars] at a distance of two cun $(4.94 \mathrm{~cm})$. Omen-reading: 'There are soldiers and death in its field (i.e. the corresponding geographic region), marquises and king are changed and enthroned'.

三月丁卯, 日入後, 眾星未見, 有流星白色, 大如斗, 從太微間 南行, 尾長尺餘。占曰:「有兵與表。」

III-dingmao.04 (31 March): ${ }^{14}$ after sunset, and before the stars had appeared, there was a flowing star white in colour, and as large as a dou-measure (two litres), which travelled south through Privy Council (Taiwei; Leo, Com and Vir) with a tail more than one chi $(24.7 \mathrm{~cm})$ in length. Omen-reading: 'There are soldiers and death'.

Yisi zhan 乙巳占, 1.10b:

今略取其理當者, 刪而次比, 以著于篇。

... selecting those whose reasoning (li) is appropriate and, by deletion and enumeration, writing them into [a] piece.

Yixing 一行 (683-727 CE), cited in Jiu Tang shu 舊唐書, 35.1307:

或者各守所傳之器以述天體, 謂渾元可任數而測, 大象可運算而閲, 終以六家之說,迭為矛盾。

Some guard the respective apparatuses of the traditions to which they belong to describe the body of heaven, saying that the primal sphere can be measured by attending to the numbers and that the great signs can be espied by the operation of counting rods - and in the end [we are left] with the theories of six schools (jia) alternating in contradictions.

Ma Chongji 馬重績 (fl. 939), cited in Jiu Wudai shi, 96.1284:

自古所用也

$\ldots$ in use since antiquity.

Han Zhongtong 韓仲通, Tonghu loujian zhidu 銅壼漏箭制度 (1162):

長三尺六寸, 方徑四分, 面各爲二十五刻, 書夜四易而百刻同。

\footnotetext{
${ }^{14}$ Something is seems to be wrong with this date, as Zhang Peiyu $(1997,189)$, has 6-

III begin on guiwei.20.
} 
3.5 chi long (1.1 m [Song]), a square diagonal of 4 fen $(1.3 \mathrm{~cm})$, the faces of which were each $25 \mathrm{ke}$ (at $14 \mathrm{fen}$ [44.2 $\mathrm{mm}$ ] per $\mathrm{ke}$ ), there being, day \& night, four changes so as to equal to $100 \mathrm{ke}$.

Sui shu 隋書, 19.529:

揆日㫡, 下漏刻, 此二者, 測天地, 正儀象之本也。

Observing ( $k u i)$ the sun gnomon and dropping the leak notch, are the root of measuring (ce) heaven and earth and correcting (zheng) sight and effigy. 


\section{Chapter 3}

Shangshu zhushu 尚書注疏, 2.21b:

帝曰:「咨! 汝羲暨和。㫷三百有六旬有六日, 以閏月定四時, 成歲。允嶅百工, 庶績咸熙。」

Thearch [Yao] said: 'Oh, you, $\mathrm{Xi}$ and $\mathrm{He}$, the year has three hundred, sixty, and six days, [and so] by means of an intercalary month should you fix the four seasons and complete the agricultural year. If you sincerely manage the hundred workers [thereby], [then your] achievements will be numerous and resplendent'.

Shangshu zhushu 尚書注疏, 1.21a:

敬授人時

... respectfully grant the seasons of man.

Zhoujiatai 周家臺 M30 Ershi 二世 1 (209 BCE) board:

以十二月戊戌嘉平月不盡四日

Jiaping [Festival] on XII-wuxu.35 (9 February 209 BCE), four days out from the end of the month.

十二月己卯 $\square$ 到

XII-jimao.16 (21 January 209 BCE) ... arrived at

賦所一籍蓆廿

court tax office a total of twenty mat cushions.

Zhangjiashan 張家山 M247 Gaozu 高祖 5-Gaohou 高后 2 (202186 BCE) bookmat:

\section{新降爲漢}

[Gaozu 5 (201 BCE):] Month IX, newly surrendered to the Han (s. 2).

六月病免

[Hui 1 (195 BCE):] Month VI, illness, relieved [of office] (s. 10).

'Taiping zhenjun shiyi nian liri' 太平鎮軍十一年曆日 $(450 \mathrm{CE})$ and 'Taiping zhenjun shier nian liri' 太平鎮軍十二年曆日 (451 CE) paper lunation table :

太平真君十二年曆日, 其年改爲正平元年

Taiping zhenjun 12 liri, this year was changed to Zhengping 1.

Zhoujiatai 周家臺 M30 Shihuang 始皇 36-7 (211-210 BCE) 'Saliu nian ri' 卅六年日:

食人米四斗, 魚米四斗

Ate four dou (8 litres) of others' refined grain, four dou of fish refined grain (reg. 2, s. 97).

澤

Marsh (reg. 5, s. 88).

有惡言

There were vicious remarks (reg. 6, s. 72). 
Yinwan 尹灣 M6 Yuanyan 元延 1 (12 BCE) 'Yuanyan yuan nian' 元 延元年 board:

元延元年三月六日, 師君兄貸師子夏八萬, 約五月盡所, 子夏若 $\square$ 卿奴 $\square \square \square \square \square \square \square \square$ 丞 $\square$, 時見者師大孟、季子叔。

Yuanyan 1-III-6, Shi Junxiong (i.e. Shi Rao) borrows 80,000 from Shi Zixia in agreement that by the end of month $\mathrm{V}$, if Zixia ... chamberlain (?) slaves ... assistant ... those who witness [this contract] at the time [of its swearing] are Shi Dameng and Ji Zishu.

Hou Han shu 後漢書, zhi 25, 3571:

掌禮儀祭祀, 每祭祀, 先奏其禮儀; 及行事, 常贊天子。每選試 博士, 奏其能否。大射、養老、大喪, 皆奏其禮儀。每月前晦, 察行陵廟。

[The minister] controls ritual ceremonies and sacrificial rites. [He] petitions on the [correct] ceremonial in advance of every sacrifice, and when it comes to the performance of [ritual] affairs, [he offers] constant assistance to the son of heaven. [He] petitions on the acceptability of erudites at every selection exam, and [he] petitions on the [correct] ceremonial in all cases of big shoots, elderly care and great mourning. [He also] makes an inspection trip of the necropoles and temples on the [last day] of every month.

Liji zhushu 禮記注疏, 21.413a:

大道之行也, 天下為公。選賢與能, 講信修睦, 故人不獨親其親, 不獨子其子, 使老有所終, 壯有所用, 幼有所長, 矜寡孤獨廢疾 者, 皆有所養。男有分, 女有歸。貨惡其棄於地也, 不必藏於己; 力惡其不出於身也, 不必為已。是故謀閉而不興, 盜戙亂賊而不 作，故外戶而不閉，是謂大同。

The practice of the great dao [created] a world-under-heaven for the public [good]. [They] selected the worthy and engaged the capable, [they] taught trust and cultivated harmony, and thus did man not treat his parents alone as parents, nor his sons alone as sons, [but] made it so that the old saw fulfilment, the strong saw employment, the young saw nurture, and [moreover] pitied the widowed, orphaned, lonely, disabled and ill [such that] all of them saw the care [they needed]. The men [all] had a [professional] part, the women [all] had a [home to] return [to], and [they] hated to throw away commodities away on the ground, but neither did they [feel the] need to collect them for personal [gain], and [they] hated not to exert their own strength [in labour], but neither did they [feel the] need to [labour] for personal [gain], and this is why scheming and secrecy never arose, and [why] robbery, theft, rebellion and banditry never came up, and so were [their] outside doors [never ever] shut - [we] call this the 'Great Uniformity'.

\section{Chunqiu 春秋:}

Wen 6

(621 bce, winter)

Wen 15-VI-1 xinchou. 38 (612 bce Apr 28)

Wen 16-V

(611 bce, summer)
閏月不告月, 猶朝于廟。

Intercalary month, no announcement of the month, [duke] still holding court at temple.

六月, 辛丑, 朔, 日有食之, 鼓用牲于社。

Sun eclipsed, drumming \& animal sacrifice at altar to the soil.

夏, 五月, 公四不視朔。

Four times the duke did not sight the new moon. 


\section{Zuo zhuan 左傳, Xi 5:}

公既視朔, 遂登觀臺以望, 而書, 禮也 ... upon sighting the new moon, the duke ascended the observation terrace to look out upon it and write it down - this is the [correct] ritual.

\section{Guliang zhuan 谷梁轉, Wen 16:}

天子告朔于諸侯, 諸侯受乎禰廟, 禮也。

The son of heaven announces the new moon(s) to the marquises, and the marquises receive them at the temples to their fathers - this is the [correct] ritual.

Liji zhushu 禮記注疏, 29.543a:

玄端而朝日於東門之外, 聽朔於南門之外, 閏月則闔門左扉, 立 於其中。皮弁以日視朝, 遂以食, 日中而餕, 奏而食。日少牢, 朔月大牢。

... wears his dark cap-robes ... to hear the new moon outside the southern gate, where, in the case of an intercalary month, [he] has the left leaf of the gate closed and stands at its centre ... every new moon it is a big pen [that is sacrificed].

Gongyang zhuan 公羊傳, Wen 6:

閏月不告月，猶朝于廟。不告月者何？不告朔也。曷為不告朔？ 天無是月也。閏月矣, 何以謂之天無是月? 是月非常月也。

'Intercalary month, no announcement of the month, [duke] still holding court at temple'. Q: What does it mean to 'not announce the month'? A: It means not announcing the new moon. Q: Why not announce the new moon? A: Because there is no such month in heaven.

\section{Zhouli zhushu 周禮注疏, 26.401b:}

正歲年以序事，頒之于官府及都鄙，頒告朔于邦國。

The Great Clerk ... rectifies the agricultural and civil years (sui nian) so as to put (ritual) affairs in order, disseminating it to offices and storehouses from the metropolis [to its] peripheries, and [also] disseminating the announcement of new moon(s) to [vassal] states and domains.

Gongyang zhuan 公羊傳, $13.168 \mathrm{a}-\mathrm{b}$ (comm.):

禮, 諸侯受十二月朔政於天子, 藏于大祖廟。

... The [correct] ritual is that the marquises receive the new moons and policies of the twelve months, from the son of heaven and store them in [their] great ancestral temples.

\section{Zuo zhuan 左傳, Wen 15 :}

日有食之, 天子不舉，伐鼓于社，諸侯用幣于社，伐鼓于朝，以 昭事神, 訓民事君, 示有等威, 古之道也。

When there is an eclipse of the sun, the son of heaven does not offer sacrifice, but has drums beaten at the altar to the soil, while the marquises sacrifice offering cloth at [their] altars to the soil and have 
drums beaten at [their] courts. [They do this] to illustriously serve the spirits, train the commoners to serve their lords and show that there are distinct ranks of authority - this is the dao of antiquity.

Jin shu 晉書, 106.2765:

置女太史于靈臺, 仰觀災祥, 以考外太史之虛實

... established a female Grand Clerk at the Numinous Terrace ... to examine the veracity of the external Grand Clerk.

Tang liu dian 唐六典, 10.13a:

每年預造來歲㦄，頒于天下。

... each year to create in advance a $l i$ of the upcoming year and promulgate it through the subcelestial realm.

Quan Tang wen 全唐文, 624.6301a:

準敕禁㫁印歷日版。劍南兩川及淮南道, 皆以版印歷日糡於市。 每歲司天臺未奏頒下新歷, 其印歷已滿天下。有乘敬授之道。

We have by imperial decree prohibited the woodblock printing of calendars. Throughout the markets of Jiannan's Two Rivers [region] (Sichuan) and Huainan Circuit there are woodblock-print liri for sale. Every year, before the [Clerk's Office] has even submitted the new $l i$ for approval and promulgated it [around], these printed $l i$ have already flooded the subcelestial realm. This is a perversion of the dao of 'reverently granting [the seasons]'.

\section{Tang yulin jiaozheng 唐語林校證, 7.671:}

僖宗入蜀。太史曆本不及江東, 而市有印貨者, 每差互朔晦, 貨 者各徵節候，因爭執。里人拘而送公，執政曰：「爾非爭月之大 小盡乎? 同行經紀, 一日半日, 殊是小事。」遂叱去而不知陰陽 之曆, 吉凶是擇, 所誤於眾多矣。

When Xizong (r. 862-88 CE) entered Shu (modern Sichuan) (amidst the Huang Chao Rebellion of $881 \mathrm{CE}$ ), the Grand Clerk's edition $l i$ was not reaching River East (south of the Yangtze). There were prints for sale at market, but they invariably confused the last and first days of the month. Each merchant maintained the veracity of his [solar cycle] and, thus, they wrangled with one another. They were detained by the men of the quarter and delivered to the authorities. The functionary in charge responded: 'You're fighting over [nothing more than the arrangement of] the big and small months? If concurrent orders are [off by] a day or a half a day, then it is really no big deal'. He then shouted [in exasperation] and walked out, ignorant of the fact that the yin-yang li, from which auspicious and inauspicious [days] are chosen, had introduced numerous errors to the masses. ${ }^{15}$

Jixian zhuji 集賢注記, cited in Yuhai 玉海, 55.43b:

自置院之後, 每年十一月内, 即令書院寫新暦日一百二十本, 頒 賜親王公主及宰相公卿等, 皆令朱墨分布, 具注柲星, 遞相傳寫, 謂集賢院本。

Ever since the establishment of the [Jixian] Academy (in $725 \mathrm{CE}$ ), the academy has been ordered to make 120 copies of the new $l i$ to disseminate to the kings and princesses of royal blood as well as the

${ }^{15}$ Tr. modified from Arrault (2003, 94-5). 
Grand Councillor, Excellencies, Ministers, etc. within month XI of every year. All of these are ordered to be distributed in red and black ink with annotations concerning the sequence of stars (li xing) so that they may be passed around for copying. [The master copies] are referred to as the Jixian Academy edition.

Tianyige cang Ming chaoben Tiansheng ling jiaozheng (fu Tang ling fuyuan yanjiu), 734:

諸每年司天監預造來年曆日, 三京、諸州各給一本。量程遠近, 節級送。樞密院散頒, 並令年前至所在。

Every year, the [Clerk's Office] is to create in advance a liri for the upcoming year, giving one copy each to the three capitals and various prefectures. [They] are to be dispatched sequentially, based on the measured distance of the journey required. The Privy Council disseminates [them] and are furthermore ordered [to do so such that they] arrive before the beginning of the civil year (nian).

Sui shu 隋書, 17.416:

梁初因齊，用宋元嘉曆。天監三年下詔定曆...至九年正月，用祖 冲之所造甲子元曆頒朔。

At the beginning, the [Xiao] Liang followed the [Xiao] Qi (479$502 \mathrm{CE}$ ) in using the [Liu] Song Epochal Excellence $l i \ldots$ In $[510 \mathrm{CE}$ ] the Jiazi..$_{01}$-origin $l i$ constructed by $\mathrm{Zu}$ Chongzhi (429-500 CE) was used to promulgate the new moons.

Tulufan chutu wenshu 吐魯番出土文書, vol. 4, 487:

為正月二月歷日未到, 准小月支, 後歷日到, 並大月, 計兩日料。 今載二月十三日牒送倉曹司充和冞訖。

Because the liri for month II had not arrived by month I, [we took the liberty of] setting it on a [stem-]branch date befitting a small month. Later, when the calendar arrived, [we] discovered that it was a double big month, and so [we] counted two days' feed. On II-13 of this year, the die invoice was dispatched to Director of the Granaries Section Chong He to purchase the full amount of grain.

Jiu Tang shu 舊唐書, 22.868:

每月一日於明堂行告朔之禮

... the announcement of the new moon ceremony be held at the Bright Hall on the first of every month.

Pilü Renxu 辟闆仁諝 (fl. 698 CE), cited in Jiu Tang shu 舊唐書, 22.868-9:

謹按經史正文，無天子每月告朔之事。惟禮記玉藻云：天子「聽 朔於南門之外。」周禮天官太宰: 「正月之吉，布政于邦國都 鄙。」干寶注云: 「周正建子之月, 告朔日也。」此即玉藻之聽 朔矣。

Careful examination of the wen of the classics and histories reveals that there is no such thing as the son of heaven's monthly announcement of the new moon. The only thing is the Record of Rites, 'Yu zao', which says that the son of heaven 'hears the new moon outside the southern gate'. The Rites of Zhou, 'Celestial Offices', Great Steward [entry reads]: 'On the first day of the first month, policies are disseminated to the states, cities and settlements'. Gan 
Bao's (d. $336 \mathrm{CE}$ ) commentary [explains]: 'Zhou month I ... is the day of the announcement of the new moon(s)'. This is the 'hearing the new moon(s)' in the 'Yu zao'.

今每歲首元日, 於通天宮受朝, 讀時令, 布政事, 京官九品以上、 諸州朝集使等咸列於庭, 此則聽朔之禮畢, 而合于周禮、玉藻之 文矣。而鄭玄注玉藻「聽朔」, 以秦制月令有五帝五官之事, 遂 云：「凡聽朔, 必特牲告其時帝及其神, 配以文王、武王。」此 鄭注之誤也。故漢魏至今莫之用。

Nowadays, on New Year's Day of every year, court is held, the seasonal ordinances (shi ling) are read, and policies are disseminated at the Tongtian Palace, while capital officials of grade nine and above, territorial representatives from the prefectures, etc. all line up in tiers in the courtyard - it is at this that the ceremony of hearing the new moon(s) is finished, and this accords with the wen of the Rites of Zhou and 'Yu zao'. Zheng Xuan's (127-200 CE) commentary to the 'Yu zao', however, posits the Qin-instituted monthly ordinances with sacrifices to the Five Thearchs, and Five Officials and then says: 'The hearing of the new moon necessitates the sacrifice of a single ox, so that one may announce oneself to the thearch and spirit of that season as well as pair oneself with King Wen (r. 1099-1050 BCE) and King $\mathrm{Wu}$ (r. 1049-1043 BCE)'. This is where the Zheng commentary is wrong $(w u)$, and that is why, from the Han and [Cao] Wei (220-65 CE) all the way to today, no one has ever done this.

按月令云「其帝太昊, 其神勾芒」者, 謂宣布時令, 告示下人, 其令詞云其帝其神耳。所以為敬授之文, 欲使人奉其時而務其業。 每月有令, 故謂之月令, 非謂天子月朔日以祖配帝而祭告之。其 每月告朔者, 諸侯之禮也。故春秋左氏傳曰: 「公既視朔, 遂登 觀臺。」又鄭注論語云: 「禮, 人君每月告朔於廟, 有祭謂之朝 享。魯自文公始不視朔。」是諸侯之禮明矣。今王者行之, 非所 聞也。

Note: the monthly ordinance's '[Spring:] its Thearch is Taihao, its spirit is Goumang' refers to the proclamation of seasonal ordinancesannouncements made to [the Son of Heaven's] subordinates and concerning 'its Thearch' and 'its spirit' in language only. This is the cultural pattern (wen) for 'reverently granting [the people the seasons]', the desire being to make people respect the seasons and devote themselves to their patrimonies. There are ordinances for every month, which is why we refer to them as 'monthly ordinances'- this does not refer to the Son of Heaven performing a sacrificial announcement to mate his ancestors with the Thearchs, on the new moon day of every month. The monthly announcement of the new moon is a ceremony for marquises. Thus does the Zuo Tradition of the Spring and Autumn Annals say, 'upon sighting the new moon, the duke ascended the observation terrace'. Furthermore, Zheng [Xuan]'s commentary to the Analects says, 'according to the rites, the lord of men announces the new moon at temple every month, and, if there be sacrifice, it is called 'audience offering'; Lu stopped sighting the new moon from the time of Duke Wen 文公 (r. 626-609 BCE)'. This is clear evidence that it is a ceremony for marquises. Nowadays, I have never heard of a king (the imperial-era equivalent of marquis) performing it.

Da Dai Liji 大戴禮記, 8.6a-11a:

明堂者, 古有之也 ……明堂者, 所以明諸侯尊卑……明堂月 令……上圓下方。九室十二堂, 室四戶，戶二牗，其宮方三百步。 
在近郊, 近郊三十里。或以為明堂者, 文王之廟也……此天子之 路寝也, 不齊不居其屋。待朝在南宮, 揖朝出其南門。

The Bright Hall once existed in antiquity ... The Bright Hall was that by which the nobility and baseness (hierarchy) of the marquises were clarified .... The Bright Hall [is where] monthly ordinances [are promulgated] ... The top is round above, and the bottom is square. [It has] nine chambers and twelve halls, each chamber [with] four doors, and each door [with] two windows. The palace is a square three hundred $b u$ to a side. [It] is located in the nearby suburbs, within thirty $l i$ [of the capital]. Some believe that the Bright Hall was the ancestral temple to King Wen ... This was the son of heaven's road chamber, no one [of] unequal [status being allowed to] dwell under its roof. Audience was awaited in the southern palace, and audience was sent off, exiting the southern gate.

Tongdian 通典, 70.1922:

後漢制, 太史每歲上其年曆。先立春、立夏、大暑、立秋、立冬, 常讀五時令。皇帝所服, 各隨五時之色。帝升御座, 尚書令以下 就席位。尚書三公郎中以令置案上, 奉以先入, 就席伏讀訖, 賜 酒一厄。

According to the stipulations of the Later Han, the Grand Clerk memorialises the annual $l i$ every year, [after which] it is customary to read the ordinances of the five seasons just prior to establishment of

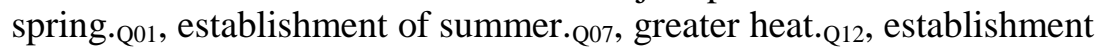
of autumn.Q13 and establishment of winter.Q19. The [vestments] worn by the emperor [on these occasions] should be of a colour appropriate to each of the five seasons. When the emperor ascends to his throne, the prefect of the Masters of Writing descends to take his mat (seat). The Masters of Writing, the Three Excellencies and the gentlemen of the palace then place the ordinances upon a desk, which is carried in and presented with both hands. They then proceed to their mats, where they genuflect until the reading is finished, at which point they are bestowed a goblet of wine.

Han shu 漢書, 10.312:

昔在帝堯立羲、和之官, 命以四時之事, 令不失其序。故『書』 云「黎民於蕃時雍」, 明以陰陽為本也。今公卿大夫或不信陰陽, 薄而小之, 所奏請多違時政。傳以不知, 周行天下, 而欲望陰陽 和調, 豈不謬哉! 其務順四時月令。

In the past, when Thearch Yao established the offices of $\mathrm{Xi}$ and $\mathrm{He}$, [he] commanded [them] to adhere to the matters of the four seasons such that [they] not get out of order. Thus it was, the Book of Documents says, that 'the masses were there and then prosperous and concordant' (2.20b) - a clear indication of the foundational importance of yin and yang. Today, some Excellencies, Ministers and grandees do not believe in yin and yang, dissembling and belittling it, and many of the petitions that they have memorialised violate seasonal policies. Passed around out of ignorance, they circulate the subcelestial realm, but if the desire is to harmonize yin and yang, then is this not absurd?! May the monthly ordinances of the four seasons be duteously observed.

Han shu 漢書, 99.4140: 
... eleven grandees of the first order to spread out [across the countryside] to exhort agriculture and sericulture and promulgate seasonal ordinances.

'Shizhe Hezhong suo ducha zhaoshu sishi yueling wushi tiao'使者和 中所督察詔書四時月令五十條:

大皇大后曰：「往者陰陽不調，風雨不時，降農自安，不堇作 【勞】，是以數被畄害，惻然傷之。惟 $\square$ 帝明王，靡不躬天之磿 （曆）數，信執厥中，欽順陰陽，敬授民時， $\square$ 勸耕種，以豐年 $\square$ ，蓋重百姓之命也。故建羲和，立四子，... 時以成歲，致喜... 其宜 $\square$ 歲分行所部各郡。」

not in accord, and wind and rain were not in time; indolent farmers were self-satisfied and did not diligently rise to their labours - this is why [they] endured numerous disasters and suffered grievously therefrom. It is the sagacious emperor and perspicacious king who never fails to embody the $l i$ numbers of heaven, faithfully upholding the balance between them, respectfully obeying yin and yang, reverently granting the people the seasons, and ... [text damaged]ingly exhorting ploughing and seeding to ensure a bounteous harvest [text damaged] ... all of this is out of weighty consideration of the hundred surnames' fate. Thus [have We] created [the office of] Xi-He and established [the offices of] the four masters [to fix the four] seasons to complete the year (sui) and deliver happiness unto [text damaged] ... may every year they split up and travel through each commandery under their respective jurisdictions'. ${ }^{16}$

Han shu 漢書, 99.B.4193:

赤眉遂燒長安宮室市里, 害更始。民飢餓相食, 死者數十萬, 長 安為虛, 城中無人行。宗廟園陵皆發掘, 唯霸陵、杜陵完。

The Red Eyebrows [rebels] had torched the palaces, halls, markets and neighbourhoods of Chang'an to damage Gengshi (r. 23-5 CE). The populace was starving from famine and eating one another, the dead [numbering] several hundred thousand. Chang'an was empty, there was no one walking [the streets] within the city. The ancestral temples, parks and necropoles had all been dug up, only [the two at] $\mathrm{Ba}$ and $\mathrm{Du}$ being [left] intact.

Qianxiang $l i$ 乾象曆, cited in Jin shu 晉書, 17.504-5:

上元己丑以來, 至建安十一年丙戍, 歲積七千三百七十八年。

From high origin, [year] jichou.26, to Jian'an 11, year bingxu.23, the year has accumulated 7378 years.

乾法…...

Supernal divisor: $1178 .$.

紀法

Era divisor: 589

周天

\footnotetext{
${ }^{16}$ Zhongguo wenwu yanjiusuo 中國文物研究所 and Gansu sheng wenwu kaogu yanjiusuo 甘肅省文物考古研究所, eds., Dunhuang Xuanquan yueling zhaotiao 敦 煌懸泉月令詔條 (Beijing: Zhonghua shuju, 2001); cf. Charles Sanft, 'Bow Control in Han China: Yuqiu Shouwang on Self-Defense', Journal of Asian History 42, no. 2 (2008): 178. Tr. modified from
} 
Circuit of heaven: 215130

通法

Communication divisor: 43026

日法…...

Day divisor: $1457 \ldots$

章歲.......

Rule years: $19 \ldots$

章月

Rule months: 235

Qianxiang $l i$ 乾象曆, cited in Jin shu 晉書, 17.505:

\section{推入紀 \\ Calculate era-entry:}

置上元盡所求年,

Set out the [number of years elapsed from] high origin to the civil year sought.

(answer: 7345 years)

以乾法除之,

Eliminate $(c h u)$ it by the supernal divisor.

(answer: $7345 \bmod 1178=278$ )

不滿乾法, 以紀法除之: 餘不滿紀法者, 入內紀甲子年也。滿法 去之，入外紀甲午年也。

[That which] does not fill the supernal divisor, eliminate $($ chu $)$ it by the era divisor. Any remainder that does not fill the era divisor is the years entered into inner era jiazi.01, [while any remainder which] fills the divisor, remove $(q u)$ it, [and that] is the years entered into outer era jiawu. 31 .

(answer: $278<589$, thus 'inner era jiazi.01')

\section{推朔}

\section{Calculate new moon:}

置入紀年, 外所求,

Set out the era-entry years, excluding that sought.

(answer: $278-1=277$ )

以章月乘之, 章歲而一, 所得為定積月，不盡為閏餘。

Mount (cheng) it by the rule months, the rule years then one (er yi) what is obtained makes the fixed accumulated months, and what is not exhausted makes the intercalary remainder.

(answer: $277 \times 235 / 19=34261 / 19$ or, in big-small notation, 3426;1)

閏餘十二以上，歲月閏。

As to the intercalary remainder, if 12 or above, the months of the year [experience] intercalation.

(answer: $1<12$, thus no intercalary month this year).

以通法乘定積月，為假積日，

Mount (cheng) the fixed accumulated months, by the communication divisor for the temporary accumulated days. 
(answer: $3426 \times 43026=147,407,076)$

滿日法為定積日，不盡為小餘。

Fill (man) the day divisor for the fixed accumulated days, and [that which] is not exhausted makes for the small remainder.

(answer: $147,407,076 \div 1457=101,171929 / 1457$, or 101,$171 ; 929$ )

以六旬去積日, 為大餘。

Remove $(q u)$ the accumulated days by 60 for the big remainder.

(answer: $101,171 \bmod 60=11$ )

命以所入紀，算外，所求年天正十一月朔日也。

Name off [the sexagenary day] according to the era entered, counting exclusively, and [that] is the new moon day of heaven I, [civil] month XI, for the year sought.

(answer: jiazi $_{.01} \rightarrow$ yichou. $_{02} \rightarrow$ bingyin $_{.03} \ldots$ jiaxu $_{.11} \rightarrow$ yihai $_{.12}$ )

求次月，加大餘二十九，小餘七百七十三，

To find the subsequent month(s), add a big remainder of 29 and small remainder of 773 .

(answer: $11 ; 929+29 ; 773=40 ; 1702$ )

小餘滿日法從大餘。

[If] the small remainder fills the day divisor, [then it] follows the big remainder.

(answer: $1702>1457$, thus carry the $0 ; 1457$ for $41 ; 245$ )

小餘六百八十四已上，其月大。

[If] the small remainder is 684 or above, [then] the month is big.

(answer: $245<648$, thus the month is small)

Qianxiang $l i$ 乾象曆, cited in Jin shu 晉書, 17.528:

凡言如盈約滿, 皆求實之除也; 去及除之, 取盡之除也。

All talk of 'as per' (ru), 'overflowing' (ying), 'simplify' (yue) and 'filling' (man) is elimination (chu) to find the dividend (i.e. division); 'remove' $(q u)$ as well as 'eliminate it' (chu zhi) are elimination (chu) to take the exhausted (i.e. modulo).

Mengxi bitan jiaozheng 夢溪筆談校證, entry 545:

唯月之盈虧, 事雖有繫之者, 如海、胎育之類, 不預歲時, 寒暑 之節，寓之曆閒可也。

Though they are connected with things like tides and gestation, the waxing and waning of the moon have nothing to do with the year and season, nor the rhythm of cold and heat, [so] it would suffice to [simply] lodge these things within [my solar] $l i$.

Jin shu 晉書, 17.498:

方於前法, 轉為精密

... final turn towards the fine and tight.

Zhang Heng et al., cited in Hou Han shu 後漢書, zhi 2, 3034:

用九道為朔，月有比三大二小，皆疏遠。

... using the nine roads, the [civil] month would see three bigs and two smalls in a row, which is all loose and off. 
Song shu 宋書, 12.260:

宋太祖頗好曆數，太子率更令何承天私撰新法。

Emperor Taizu of [Liu-]Song (r. 424-464 CE) was deeply fond of $l i$ numbers, and Director of the Watches for the Heir Apparent He Chengtian privately wrote (si zhuan) a new method $(f a)$.

He Chengtian 何承天 (370-447 CE), cited in Song shu 宋書, 12.262:

合朔月蝕, 不在朔望, 亦非曆意也。

... having syzygy and lunar eclipse not on new and full moon is counter to the very idea of $l i$.

Qian Lezhi 錢樂之 (fl. 436-44 CE), cited in Song shu 宋書, 12.264:

又承天法, 每月朔望及弦, 皆定大小餘, 於推交會時刻雖審, 皆 用盈縮, 則月有頻三大、頻二小, 比舊法殊為異。舊日蝕不唯在 朔, 亦有在晦及二日。公羊傳所謂「或失之前, 或失之後」。愚 謂此一條自宜仍舊。

Re Chengtian's method: the new, full and quarter moons of each month all fix the big and small remainder, which, while prudent for calculating the time notch of crossing coincidence (eclipse) - for which surplus-shrinkage (i.e. speed correction) is always used - it does [result in] the [civil] month experiencing three bigs and two smalls in a row, which is markedly different from the old method (jiu fa). In the old [way], solar eclipse does not occur on new moon alone but also on last and second day of the month, which is what the Gongyang Tradition refers to as 'some miss ahead of the mark, some miss behind' (Yin 3). In our humble opinion, it is advisable that [we] persist in the old [way] on this one point.

Pi Yanzong 皮延宗 (fl. 444 CE), cited in Song shu 宋書, 12.264:

若晦朔定大小餘, 紀首值盈, 則退一日, 便應以故歲之晦, 為新 紀之首。

If the last and first day of the month fix the big and small remainder [such that] era head falls on a surplus (a positive speed correction), then [one] must fall back one day and take the last day of the previous year (sui) as the head of the new era.

Song shu 宋書, 12.264:

改新法依舊術, 不復每月定大小餘, 如延宗所難, 太史所上。 ... amending his new method according to the old procedure, no longer fixing the big and small remainder for each [civil] month.

Sui shu 隋書, 17.417:

制詔更造新曆……月朔以遲疾定其小餘，有三大二小。 ... issued an edict for the creation of a new li ... that fixed the small remainder of new moon via slow-fast [so as] to have three bigs and two smalls.

Liu Xiaosun and Liu Zhuo, cited in Sui shu 隋書, 17.424:

唯識轉加大餘二十九以為朔, 不解取日月合會準以為定。 
... only knowing to add a greater remainder of 29 for the new moon without understanding to take the conjunction-coincidence (hehui) of sun and moon as the standard for fixing [it].

Liu Zhuo 劉卓 (455-610 CE), cited in Sui shu 隋書, 17.424:

此三人者, 前代善曆, 皆有其意, 未正其書。但曆數所重, 唯在 朔氣。朔為朝會之首, 氣為生長之端, 朔有告餼之文, 氣有郊迎 之典, 故孔子命曆而定朔旦冬至, 以為將來之範。今孝孫曆法, 並按明文, 以月行遲疾定其合朔, 欲令食必在朔, 不在晦、二之 日也。縱使頻月一小、三大，得天之統。

These three men - the li experts (shan li) of previous dynasties - were all of this intention but had yet to correct their writings. What matters in $l i$ numbers are new moons and qi. The [first] new moon crowns [the calendar of] court audiences, and the [first] $q i$ is the beginning of the growth of life; in the new moon is invested the cultural pattern (wen) of declarations and food offerings, and in the $q i$ is invested the ceremonies of the suburban sacrifice and reception - thus it was that Confucius (551-479 BCE) mandated $l i$ and fixed (ding) the new moon and winter solstice as a model for the future [in the Spring and Autumn Annals]. Today, Xiaosun's li method (li fa) accords with both the manifest and patterns (i.e. experience and classical precedent): it fixes (ding) the syzygy by means of slow-fast lunar motion, desiring to make [solar] eclipse necessarily fall on new moon, not on the last or second day of the month. Even if it concatenates the months 'one small, three big', [it does so to] get at the integrity (tong) of heaven.

Sui shu 隋書, 17.424:

飾非致難。

... raised objection by decorating wrongness.

Jiu Tang shu 舊唐書, 79.2714:

本來不知。

... had no idea in the first place.

Han shu 漢書, 99A.4077-8:

徙者以千萬數

... transplanted in numbers of thousands \& myriads.

Hou Han shu 後漢書, zhi 2, 3041:

食當以見為正，無遠近

... [only the actual] appearance of an eclipse should be counted as correct, there being no 'distant' or 'close'. 


\section{Chapter 4}

Han shu 漢書, 21A.973:

三苗亂德，二官咸廢。

... the Sanmiao corrupted their virtue, and both offices were abandoned.

Han shu 漢書, 21A.973:

復育重、黎之後。

... re-educate Chong and Li's descendants.

Shangshu zhushu 尚書注疏, 7.102a:

羲和廢厥職，酒荒于厥邑。

... the $\mathrm{Xi}$ and $\mathrm{He}$ [brothers] deserted their posts, losing themselves in alcohol in their [respective] fiefs.

Hou Han shu 後漢書, zhi 2, 3042:

「前郎中馮光、司徒掾陳晃各訟曆, 故議郎蔡邑共補續其志。今 洪其詣修, 與漢相參, 推元 (謂) 〔課〕分, 考校月食。審己巳 元密近, 有師法, 洪便從漢受; 不能, 對。」

[Liu] Hong (fl. 167-206 CE) shall go forthwith to [Prefect Grand Clerk] Xiu to compare (can) against Han, calculating origins and testing (ke) parts, examining and collating (kao jiao) lunar eclipses. [If] upon circumspection (shen) [Hong finds Han's] jisi.06 origin tight and close (mi jin) and that [Han] has a master('s) method (shifa), then Hong is to receive it from Han. If unable to do so, [please] respond.

Hou Han shu 後漢書, zhi 2, 3043:

雖有師法, 與無同。課又不近密。

... though [Wang Han] has a master('s) method it is the same as if he had none; the test results $(k e)$, moreover, were not close and tight (jin mi).

Lu Jiuci wen shu yu Chen $Q i$ 魯久次問數于陳起:

魯久次問數于陳起曰: 久次讀語、計數弗能竝撴（徹），欲撴 （徹）一物, 可（何）物為急？”陳[4-142]起對之曰: “子為弗 能竝墩（徹），舍語而㬿（徹）數=，（数）可語殴（也）, 語 不可数殴（也）”…... [4-144]

Lu Jiuci inquired about numbers from Chen Qi, saying, '[I], Jiuci, read speech $(y u)$ and count numbers $(s h u)$ but cannot fathom the two at once. [I] want to fathom [at least] one [of these] things, [so] which thing is [the most] urgent?' Chen Qi replied to him, saying, 'If my good sir cannot fathom both at once, then abandon speech and fathom numbers, [for] numbers can speak, [but] speech cannot number'. ${ }^{17}$

Jin shu 晉書, 17.503:

\footnotetext{
${ }^{17}$ Han Wei 韓巍, 'Beida cang Qin jian Lu Jiuci wen shu yu Chen Qi chudu’ 北大藏 秦簡『魯久次問數于陳起』初讀, Beijing daxue xuebao (zhexue shehui kexue ban) 北京大學學報（哲學社會科學版） 52, no. 2 (2015): 30.
} 
自黃初已後, 改作曆術, 皆㽎酌乾象所減斗分、朔餘、月行 陰陽 遲疾, 以求折衷。洪術為後代推步之師表, 故先列之云。

From the Yellow Inception period $(220-6 \mathrm{CE})$ on, the reform and creation of $l i$ procedures all pored over the Supernal Icon's Dipper parts reduction, syzygy remainder, and yin-yang and slow-fast [sequences] of lunar motion in search of compromise. Hong's procedures were the exemplar (shibiao) of calculation for the subsequent age, and thus [do I] lay them out as follows.

Jin shu 晉書, 17.498:

漢靈帝時, 會稽東部尉劉洪, 考史官自古迄今曆注, 原其進退之 行, 察其出入之驗, 視其往來, 度其終始, 始悟四分於天疏闊, 皆斗分太多故也。更以五百八十九為紀法, 百四十五為斗分, 作 乾象法, 冬至日日在斗二十二度, 以術追日、月、五星之行, 推 而上則合於古，引而下則應於今。

In the time of Emperor Ling of Han (168-89 CE), chief commandant of Kuaiji Eastern Regiment, Liu Hong, examined the Clerk's Office's li notes [all the way] from antiquity to his day. [He] traced the motions of advance and retreat, and [he] verified (yan) the risings and settings; [he] watched the goings and comings, and [he] $d u$-measured the ends and beginnings, and [he] first awoke (shi wu) [to the realisation] that the Quarter-remainder [li] was loose and wide (shu kuo) of heaven and that it was all because the Dipper parts was too large. [He] changed the era divisor to 589, and the Dipper parts to 145, and he created the Supernal Icon method, with the winter solstice.Q22 sun at Dipper.L08 $22 d u$, seeking the motion of the sun, moon and five [planets] via procedures. [He] calculated, and above [it] matched with antiquity, and below [it] responded to the present.

其為之也, 依易立數, 遁行相號, 潛處相求, 名為乾象曆。又創 制日行遲速, 兼考月行, 陰陽交錯於黃道表裏, 日行黃道, 於赤 道宿度復有進退。方於前法, 轉為精密矣。

What he did was establish numbers based on the Changes [such that] they called out to one another in hidden motion and sought each other out from secret parts - and [at this he] named it the 'Supernal Icon $l i$ '. Also, [he] created the solar/daily motion slow-fast (speed correction) while concurrently investigating ( $k a o$ ) lunar motion, [concluding that] yin and yang (i.e. negative and positive latitude) cross inside and outside the yellow road, and that the sun travels on the yellow road, experiencing advance and retreat in terms of red-road lodge $d u$ (see Section 2.1.4) - and only with this was there a turn (zhuan) towards the fine and tight (jing $\mathrm{mi}$ ) relative to prior methods.

獻帝建安元年, 鄭玄受其法, 以為窮幽極微, 又加注釋焉。

In [196 CE], Zheng Xuan (127-200 CE) received his method, and considering it to plumb all that is recondite and crown all that is subtle, he further added commentary and explanation to it.

\section{Analects XV.11:}

行夏之時, 乘殷之輅, 服周之冕, 樂則韶舞。

Implement the seasons of Xia, ride the carriage of Yin and wear the cap of Zhou, while, for music, it's the Shao and $W u$.

Zuo zhuan, Shao 17:

夏數得天 
The Xia numbers get heaven.

Jin shu 晉書, 17.498-9:

魏文帝黃初中, 太史令高堂隆復詳議曆數, 更有改革。太史丞韓 翊以為乾象減斗分太過, 後當先天, 造黃初曆, 以四千八百八十 三為紀法，千二百五為斗分。

Midway through the Yellow Inception period (220-6 CE) ... Prefect Grand Clerk Gaotang Long (d. c.240 CE) made repeated and detailed deliberation (yi) on $l i$ numbers and [the need for] reform. Assistant to the Grand Clerk Han Yi thought that the Supernal Icon $l i$ went too far in reducing the Dipper parts and that it would later slip ahead of heaven, so [he] constructed the Yellow Inception $l i$, using an era divisor of 4,883, and a Dipper parts of 1,205.

其後尚書令陳最奏, 以為: 「曆數難明, 前代通儒多共紛爭。黃 初之元以四分曆久遠疏闊, 大魏受命, 宜改曆明時, 韓翊首建, 猶恐不審, 故以乾象互相參校。其所校日月行度, 弦望朔晦, 歷 三年, 更相是非, 無時而決。案三公議皆綜盡典理, 殊塗同歸, 欲使效之瓐璣，各盡其法，一年之間，得失足定。」

Later, Prefect of the Masters of Writing Chen Qun (d. 237 CE) submitted a petition, which went, ' $L i$ numbers are difficult to comprehend and have been a point of much contention among the expert scholars (tong ru) of the previous age. At the inauguration of the Yellow Inception reign, the Quarter-remainder $l i$ had long been far-off (yuan), loose (shu) and wide (kuo). The Great Wei has received the mandate, and it is time to reform the $l i$ and illuminate the seasons. Han Yi was the first to establish [a new li], afraid that [it] was not [sufficiently] circumspect (shen), [however], [he] thus referenced and compared (can jiao) [it] against the Supernal Icon [li]. What [he] compared was the motion- $d u$ of sun and moon and the quarter, full, new and dark moon (i.e. lunar phases). Over the course of three years, [people] exchanged [accusations] of right and wrong, which were at no time [ever] resolved. According to the Three Excellencies' deliberation (yi), everyone gathered everything together and put it to a hearing to arrive by different paths at the same conclusion: that [they] desired that it be proven (xiao) at the rotating mechanism (xuanji, i.e. armillary sphere) - each to the utmost of their methods $(f a)$ - such that in one year's time there should be sufficient [grounds] to determine their respective success/failure (de shi)'.

奏可。

The petition was approved.

Sanguo zhi 三國志, 47.1129:

改四分, 用乾象曆。

... reforming the Quarter-remainder to use the Supernal Icon li.

Sanguo zhi 三國志, 25.719:

意過其通者

... [his] intentions surpassed his expertise.

Jin shu 晉書, 17.503:

校議未定，會帝崩而寝。 
... before comparison and deliberation had been settled, the emperor died, and [the matter] was laid to rest.

Wei shu 魏書, 107A.2659:

光和中易以乾象, 魏文時用韓靖所定。

$\ldots$ in [178-84] there was a change to the Supernal Icon, and in [220-

6 CE they] used that fixed by Han Yi.

Shushu jiyi 數述記遺, $1 \mathrm{~b}$ :

備㦄邱获, 林壑必過。乃於太山, 見劉㬝稽博識多聞, 徧於數術。 余因受業, 頗染所由。余時問曰:「數有窮乎? 」。會稽 $1 \mathrm{~b}$ 曰: 「吾兽游天目山中。見有隱者, 世莫知其名, 號曰天目先生。余 亦以此意問之。先生曰: 『世人言三不能比兩, 乃云捐悶與四 維』。

Trekking all through hill and mount, the woods and gullies that need be passed, [I] finally [arrived] at Mt Tai. [There I] saw Liu Kuaiji, broadly knowledgeable and well informed, everywhere in numbers and procedures (shu shu). I thereupon received [my] patrimony, rather infected by whence it came. I at one time asked, 'Is there any [point at which] numbers are exhausted?' Kuaiji said, 'I once was roaming in the Eye of Heaven Mountains and saw that there was a recluse [living] there. No one in our day knows his [real] name, nicknaming him 'Eye of Heaven Sensei' (Tianmu Xiansheng). I thought to ask him the same question, and Sensei said [to me], 'The people of this day and age say that a three's no match for two, speaking about [the games] cutboredom and four corners'.

Jin $s h u$ 晉書, 17.503:

其劉氏在蜀，仍漢四分曆。吳中書令䦏澤受劉洪乾象法於東萊徐 岳, 又加解注。中常侍王蕃以洪術精妙, 用推渾天之理, 以制儀 象及論，故孫氏用乾象曆，至吳亡。

The House of Liu were in Shu (221-63 CE), which kept the Han Quarter-remainder $l i$. The [Sun] Wu prefect of the palace writers, Kan Ze (d. $243 \mathrm{CE}$ ), received Liu Hong's Supernal Icon method from Xu Yue of Donglai and added exegesis and commentary to it. Regular Palace Attendant Wang Fan considered Hong's procedures fine and marvellous, and [he] used them to extrapolate the principles of sphere heaven to build a sight [and/as] effigy as well as a discursive. Thus it was that the Sun Clan used the Supernal Icon $l i$ until the demise of $\mathrm{Wu}$ (222-80 CE).

Jin shu 晉書, 17.503:

至明帝景初元年, 尚書郎楊偉造景初曆, 表上。帝遂改正朔, 施 行偉曆, 以建丑之月為正, 改其年三月為孟夏, 其孟、仲、季月 雖與夏正不同，至於郊祀蒐狩，班宣時令，皆以建寅為正。三年 正月帝崩, 復用夏正.

In Emperor Ming, Luminous Inception 1 (237 CE), Gentleman of the Masters of Writing Yang Wei constructed the Luminous Inception $l i$ and submitted it to the throne. The emperor thereupon reformed the first month and implemented [Yang] Wei's li. [He] took the month established at chou. 02 as the first month, changing month III of that year to the first month of summer (month IV). Though the first, middle and last months of the seasons were different from those [counted from] the Xia first month, when it came to the suburban 
sacrifices, the spring and winter hunts, and the proclamation of seasonal ordinances, all of these [were done] according to a first month established at in. $_{\text {в03 }}$ (as per the old Xia calendar). In year 3 $(239 \mathrm{CE})$ the emperor died, and [the court] reverted to the Xia first month.

Song shu 宋書, 14.328-9:

黃初以來, 諸儒 共論正朔, 或以改之為宜, 或以不改為是, 意取 駁異, 于今未決。朕在東宮時聞之, 意常以為夫子作春秋, 通三 統，為後王法。正朔各從色，不同因襲。自五帝、三王以下，或 父子相 繼, 同體異德; 或納大麓, 受終文祖; 或尋干戈, 從天行 誅。雖遭遇異時, 步驟不同, 然未有不改正朔, 用服色, 表明文 物，以章受命之符也。由此言之，何必以不改為是邪。」

Since the Yellow Inception, Ruists have all been discussing the first month, some considering it advisable to reform, some considering it right to not reform, and, with the intention of selecting from difference and dissent, [the matter] has gone unresolved to our day. In [We] heard of this in [Our] time at the Eastern Palace (as heir apparent), being always of the opinion that the master (Confucius) had created the Spring and Autumn Annals and circulated three-concordance [metaphysics] as a model for later kings - that the first month of each should follow [its] colour [correlate], which differs in accordance with inheritance. Since the [time of] Five Thearchs and Three Kings, [this] sometimes passed between father and son, [who were] of the same body but different virtues, sometimes (referring to Shun) by being 'sent to the great plains at the foot of the mountains' and 'receiving [the former ruler's] retirement in the temple of the Cultured Ancestor' (Shangshu zhushu 尚書注疏, 3.34b-35b), and sometimes by taking up shields and dagger-axes to administer punishment at the bidding of heaven. Though [they] took different steps in different times, there has never been a case of not changing the first month, using robe-colour or elucidating of cultured (ritual) objects to display the tokens of having received the mandate. Speaking about it from this [perspective], why mustn't reforming [the first month] be correct?

Sanguo zhi 三國志, 25.709:

遷侍中, 猶領太史令。

... transferred to palace attendant while kept on as Prefect Grand Clerk.

Zizhi tongjian 資治通鑒, 120.36a:

得夏太史令張淵、徐辯, 復以為太史令。

... obtained the Xia Prefect grand clerks Zhang Yuan and Xu Bian and reinstated them as prefect grand clerks.

Jin shu 晉書, 18.536:

今改元為景初, 宜曰景初曆。

Now that the era has been changed to Luminous Inception, it is apt that [this] be called the Luminous Inception $l i$.

Song shu 宋書, 14.332-3:

省奏事，五內斷絕，奈何奈何！烈祖明皇帝以正日棄天下，每與 皇太后念此日至，心有剥裂。不可以此日朝吿辟，受慶賀也。月 
二日會, 又非故也。聽當還夏正月。雖違先帝通三統之義, 斯亦 子孫哀慘永懷。又夏正朔得天數者, 其以建寅之月為歲首。

Upon reflection of the matter of [your] memorials, [We feel as if] Our five organs are severed. What to do? [Oh], what to do? [Our] meritorious ancestor, Emperor Ming, abandoned the subcelestial realm on New Year's Day, and every time [We] think about the approach of this day with the Empress Dowager [We feel as if] our hearts are being peeled and torn. [We] cannot hold court for the mass of lords on this day, for that is to receive praise and felicitation, and meeting on the second is furthermore against [all] precedence. [We] have heard that it is right to return to the Xia first month, and though [We] violate the former emperor's understanding of the three concordances, this is, for its part, [an expression of His] descendants' grievous misery and eternal remembrance. Moreover, since the Xia first month 'gets the numbers of Heaven' (Zuo zhuan, Shao 17), may [this] the month established at in $_{\text {.в03 }}$ be made the beginning of the year.

Jin shu 晉書, 17.503:

武帝踐阼, 泰始元年, 因魏之景初曆, 改名泰始曆。楊偉推五星 尤疏闊, 故元帝渡江左以後, 更以乾象五星法代偉曆。

When Emperor Wu [of Jin] (r. 265-90 CE) ascended the throne in Grand Beginning 1 (265 CE), [he] inherited the Luminous Inception $l i$ of the [Cao] Wei but changed its name to the 'Grand Beginning $l i$ '. Yang Wei's [procedures for] calculating the five [planets] were particularly loose and wide (shu kuo), thus [this part of Yang] Wei's $l i$ was swapped out for the Supernal Icon's five[-planet] method after Emperor Yuan (r. 317-22 CE) crossed to the left bank of the Yangtze (in $317 \mathrm{CE}$ ).

Jin shu 晉書, 17.499-503:

太史令許芝云：「劉洪月行術用以來且四十餘年，以復覺失一辰 有奇。」

Prefect Grand Clerk Xu Zhi said: 'Liu Hong's procedure for lunar motion has been in use for more than forty years now, and [it] is repeatedly perceived to miss the mark (shi) by one chen and some odd [fraction]'.

孫欽議: 「史遷造太初, 其後劉歆以為疏, 復為三統。章和中, 改為四分, 以儀天度, 考合符應, 時有差跌, 日蝕覺過半日。至 喜平中，劉洪改為乾象，推天七曜之符，與天地合其敘。」

Sun Qin yi-opined: '[Grand] Clerk [Sima] Qian (c.145-c.86 BCE) constructed the Grand Inception. Afterwards, Liu Xin (c.50 BCE$23 \mathrm{CE})$ considered it loose $(s h u)$ and thus made the Triple Concordance. In [87-8 CE], this was reformed to the Quarterremainder. Using the heavenly $d u$ of the [sphere] sight to examine (kao) and match (he) foretoken and response (prediction and observation), [it was discovered that] the time experienced error and slip (cha die), overshooting solar eclipses by a half-day. By [172$8 \mathrm{CE}$, Liu Hong had reformed to the Supernal Icon, the foretokens of the seven luminaries of heaven that it predicts $\left({ }^{*}\right.$ buo $\left.^{\mathrm{B}}\right)$ matching the order that between heaven and earth exists $\left({ }^{*} \mathrm{zia}^{\mathrm{B}}\right)$.'

董巴議云: 「聖人迹太陽於暑景, 效太陰於弦望, 明五星於見伏, 正是非於晦朔。弦望伏見者, 曆數之綱紀, 檢驗之明者也。」 
Dong Ba yi-opined: 'The sage men tracked the [sun] from gnomon shadows, verified (xiao) the [moon] from quarter and full moons, elucidated the [planets] from appearances and concealments, and settled right and wrong from the first and last days of the month. Quarter moons, full moons, concealments and appearances are the net threads (ji) of $l i$ numbers and are brilliant for inspection and verification (jian yan).'

徐岳議: 「劉洪以曆後天, 潛精內思二十餘載, 參校漢家太初、 三統、四分曆術。

$\mathrm{Xu}$ Yue yi-opined: 'Liu Hong absorbed [himself] in inner contemplation for more than twenty years with the $l i$ 's lag behind heaven, referencing and comparing the $l i$ procedures of Han experts in the Grand Inception, Triple Concordance and Quarter-remainder [li].

課弦望於兩儀郭間, 而月行九歲一終, 謂之九道; 九章, 百七十 一歲, 九道小終; 九九八十一章, 五百六十七分而九終, 進退牛 前四度五分。學者務追合四分, 但減一道六十三分, 分不下通, 是以疏闊, 皆由斗分多故也。課弦望當以昏明度月所在, 則知加 時先後之意, 不宜用兩儀郭間。

If one tests $(k e)$ the quarter and full moons from the two sights' perimeter intervals, [one finds that] lunar motion terminates (repeats) once every nine years - what [we] call the 'nine roads'. In nine rules (zhang) - 171 years - the nine roads [makes a] small termination, and in nine nines - 81 rules - there are 567 parts and nine [small] terminations, advancing and retreating from four $d u$ and five parts before Ox.L09 (the winter solstice). Scholars duteously sought to match this with the Quarter-remainder by simply subtracting the 63 parts of one road such that the parts would not carry down. This is why it was loose and wide (shu kuo) - it was because the Dipper parts was too large. If one tests $(k e)$ quarter and full moons via $d u$ measuring the position of the moon at dusk and dawn, then one will know whether the added hour is ahead or behind; it is not [however] advisable to use the two sights' perimeter intervals.

洪加太初元十二紀, 減十斗下分, 元起己丑, 又為月行遲疾交會 及黃道去極度、五星術, 理實粹密, 信可長行。

Hong added twelve eras (ji) to the Grand Inception $l i$ origin, reduced ten from the fraction at the end of Dipper.L08, and started [his] origin from year jichou. ${ }_{26}$. In addition, [he] made procedures for the slowfast crossing coincidence (speed correction) as well as yellow-road north polar distance (polar co-latitude) of lunar motion and for the [planets]. [He] reasoned out (li) their truths in a way that was pure and tight and that $[\mathrm{I}]$ believe can operate for a long time [to come].

今韓翊所造, 皆用洪法, 小益斗下分, 所錯無幾。翊所增減, 致 亦留思, 然十術新立, 猶未就悉, 至於日蝕, 有不盡效。

Now, all of what Han Yi has constructed uses Hong's methods $(f a)$. [He] slightly increases the fraction at the end of Dipper. ${ }_{\text {L08 }}$, but there is barely any difference. As for Yi's additions and subtractions, their rendering was not without thought, but [his] ten procedures are newly established and are as yet imperfect, being sometimes less than completely effective (xiao) as regards solar eclipses.

效曆之要, 要在日蝕。喜平之際, 時洪為郎, 欲改四分, 先上驗 日蝕：日蝕在晏, 加時在辰, 蝕從下上, 三分侵二, 事御之後如 洪言，海內識真，莫不聞見，劉歆以來，未有洪比。」 
Of the essentials of $l i$ testing (xiao), the [most] essential is the solar eclipse. In [172-8 CE], Hong was at the time a court gentleman and wished to reform the Quarter-remainder, [so he] first verified (yan) it above (i.e. in heaven and/or in writing to the emperor) via solar eclipse. The eclipse was on a clear day, the added hour was at chen.в05 (08:00-10:00), and the eclipse went from bottom to top, intruding two-thirds (over the disk of the sun). After the matter had been inspected, it was [found to be] like Hong said. [All] within the oceans recognised the truth (zhen) of it, and there was no one who did not hear of it. Ever since Liu Xin, there has been no match for Hong.'

\section{凡課日月蝕五事，乾象四（遠）【近】，黃初一近。}

... Out of a total of five tests $(\mathrm{ke})$ of solar and lunar eclipses, the Supernal Icon had four (fars) [closes], and the Yellow inception had one close.

翊於課難徐岳：「乾象消息但可減, 不可加。加之無可說, 不可 用。」

Yi challenged Xu Yue about the test results $(k e)$ : 'The Supernal Icon ebb-and-flow can only be subtracted, it cannot be added. There is no way to explain adding it. [This] is useless!'

岳云: 「本術自有消息, 受師法, 以消息為奇, 辭不能改, 故列 之正法消息。」

Yue said, 'The original procedure itself has ebb-and-flow; [I] received the master's method ( shi fa), and it is the ebb-and-flow that makes [it] astonishing. [I] am afraid that [this] cannot be changed (gai) and thus have arranged [here] the proper method of ebb-and-flow.'

翊術自疏。

Yi backed down.

……凡四星見伏十五: 乾象七近二中, 黃初五近一中。

... Out of a total of fifteen appearances and hidings of four [planets], the Supernal Icon had seven closes and two hits, and the Yellow Inception had five closes and one hit.

郎中李恩議：「以太史天度與相覆校，二年七月、三年十一月望 與天度日皆差異, 月蝕加時乃後天六時半, 非從三度之謂, 定為 後天過半日也。」

Gentleman of the Interior Li En yi-opined: 'By comparison with the Grand Clerk's heavenly $d u$ (as calculated from the official Quarterremainder $l i$ ), on the other hand, [one notes that there] the full moons of 2-VII (21 August 221) and 3-XI (5 January 223) are not even on the same day as the [real] heavenly $d u$ - the added hour of lunar eclipse being six [double]-hours and a half (thirteen hours) behind heaven. This is not what one would call "trailing by three $d u$ "; [we] determine [rather] a lag behind heaven in excess of a half-day.'

董巴議曰: 「昔伏羲始造八卦, 作三畫, 以象二十四氣。黃帝因 之, 初作調曆。歷代十一, 更年五千, 凡有七曆。

Dong $\mathrm{Ba} y i$-opined: 'In the past, Fuxi first created (zao) the eight trigrams and invented $(z u o)$ their three lines in order to symbolise (xiang) the twenty-four qi. The Yellow Emperor followed suit and first invented (zuo) the Adjusted li. Over eleven dynasties and five thousand successive years there was a total of seven $l i$. 
顓頊以今之孟春正月為元, 其時正月朔旦立春, 五星會于天廟, 營室也, 冰凍始泮融解, 蟄蟲始發, 雞始三號, 天曰作時, 地曰 作昌, 人曰作樂, 鳥獸萬物莫不應和, 故顓頊聖人為曆宗也。

Zhuanxu made the first month of spring, month I, [we use] today his origin. At the time, on the first day of the first month, on the establishment of spring. Q01, the five [planets] congregated at Heaven's Temple - that is, Hall. L13 $_{\text {- }}$ as the ice first began to melt, the hibernating insects first came out, and the cocks first began to cry three times. It was the rise (zuo) of seasons in heaven, the rise $(z u o)$ of prosperity on earth and the rise (zuo) of music/joy among man, and none of the birds, beasts or myriad creatures did not respond to one another in harmony. Thus is the sage man Zhuanxu the progenitor of $l i$.

湯作殷曆, 弗復以正月朔旦立春為節也, 更以十一月朔旦冬至為 元首，下至周魯及漢，皆從其節，據正四時。夏為得天，以承堯 舜, 從顓頊故也。禮記大戴曰「虞夏之曆, 建正於孟春」, 此之 謂也。」

Tang invented $(z u o)$ the Yin $l i$, which no longer took [the coincidence of] the establishment of spring. ${ }_{\mathrm{Q} 01}$ with the first day of the first month as its node, changing [instead] to an origin head [at the coincidence of] winter solstice.Q22 with the first day of the eleventh month. Down to Zhou, $\mathrm{Lu}$ and Han, everyone followed this node, on which the corrections of the four seasons (regulated intercalation) have been [hitherto] based. The Xia won the support of heaven so as to succeed Yao and Shun by following Zhuanxu. Dai the Elder's Record of Rites says, 'The $l i$ of the Yu Xia established its first month on the first month of spring' (Da Dai Liji, 9.11b), that is what this refers to.'

楊偉請: 「六十日中疏密可知, 不待十年。若不從法, 是校方員 棄規矩, 考輕重背權衡, 課長短廢尺寸, 論是非違分理。若不先 定校曆之本法, 而懸聽棄法之末爭, 則孟軻所謂「方寸之基, 可 使高於岑樓」者也。

Yang Wei pleaded: 'Looseness and tightness can be known in sixty days, one [need] not wait ten years. If you do not follow the/a method $(f a)$, this is [like] abandoning the compass and T-square when checking (jiao) squareness and roundness; it is [like] forsaking the scale and balance when investigating ( $\mathrm{kao}$ ) lightness and heaviness; it is [like] abandoning the chi and cun (ruler) when testing (ke) length and shortness; and it is [like] turning away from distinctions and principles when discoursing upon right and wrong. If one does not first fix a 'root' method for checking $l i$, carelessly entertaining 'branch' disputes that abandon method ( $f a$ ), then this is what Mencius (fl. 320 $\mathrm{BCE})$ refers to as "being able to make a one-cun square of foundation reach a greater height than a tall building (by suspending it where it doesn't belong)" (Mencius VIB.1).

今韓翊據劉洪術者, 知貴其術, 珍其法。而棄其論, 背其術, 廢 其言, 違其事, 是非必使洪奇妙之式不傳來世。若知而違之, 是 挾故而背師也; 若不知而據之, 是為挾不知而罔知也。」

Now, from Han Yi's reliance on Liu Hong's procedures [we see that he] knows to esteem his procedures and treasure his methods, and yet [he] dismisses his discourse, forsakes his procedures, abandons his words and strays from his endeavour, the inevitable result of which will be to stop Hong's unique and marvellous model (shi) from being transmitted to future ages. If [the case be that he] is straying from it knowingly, then [he] has intentionally forsaken [the] master; if [it be that he] is basing himself upon it unknowingly, then [he] has ignorantly arrived at a confused understanding.' 
Yixing 一行 (683-727 CE), cited in Xin Tang shu 新唐書, 17B.622:

然本以消息為奇, 而術不傳

... it was originally the ebb-and-flow that was [the most] astonishing, but the procedure was not passed down.

Yang Wei 楊偉, cited in Jin shu 晉書, 18.536

……先密後疏而不可用.......

... first tight and later loose and, thus, inadvisable for use. ...

是以臣前以制典餘日, 推考天路, 稽之前典, 驗之以蝕朔, 詳而 精之, 更建密曆, 則不先不後, 古今中天……臣之所建景初曆, 法數則約要, 施用則近密, 治之則省功, 學之則易知。雖復使研 桑心算, 隸首運籌, 重黎司暑, 羲和察景, 以考天路, 步驗日月, 究極精微, 盡術數之極者, 皆未能並臣如此之妙也。是以累代曆 數, 皆疏而不密, 自黃帝以來, 常改革不已。

It is for this [reason] that Your humble servant has previously, in days off from attending to the canons [of state], calculated and tested the heavenly road, examining it in prior literature, and verifying it in eclipse syzygies; detailing and honing it, and establishing anew a tight li that be neither ahead nor behind, but on the mark in heaven, past and present ... This Luminous Inception li established by Your humble servant, its methods and numbers are concise and essential, and its implementation and use are close and tight; work on it, and one will find it saves time; study it, and one will find it easy to understand. Now, even if one made [the legendary mathematicians Ji] Yan and Sang [Hongyang] perform mental calculations, [sage-time inventor of mathematics] Li Shou operate the counting rods, Chong and Li direct the gnomon, and $\mathrm{Xi}$ and $\mathrm{He}$ examine the shadow to investigate the road(s) of heaven, and calculate and verify the sun and moon, to plumb the extremes of fineness and subtlety, and to exhaust the limits of procedures and numbers $(s h u s h u)$ - none of this would nearly so marvellous as [the marvel that is] I, your humble servant. It is for this [reason] that the $l i$ numbers of the accreted ages are all loose and not tight, and why, since the time of the Yellow Emperor, they have been reformed without end. ${ }^{18}$

Cai Yong 蔡邑 (133-92 CE), cited in Hou Han shu 後漢書, zhi 2, 3038-9:

是則雖非圖讖之元, 而有效於前者也……但言圖讖, 所言不服。

This is a case where [an origin] was effective over its predecessors despite it not being an origin [that appears in] diagrams and prophecies... talk only of diagram and prophecy [literature], and what [they] say does not convince.

Sui shu 隋書, 20.561:

張子信……始悟日月交道, 有表裏遲速

Zhang Zixin... was the first to awaken [to the fact] that the crossed roads of sun and moon [both] have inside and outside (displacements in latitude) and slow and fast (pseudo equations of centre)

${ }^{18}$ Cf. Guan Yuzhen 關瑜楨, 'Eclipse Theory in the Jing Chu Li: Part I. The Adoption of Lunar Velocity', Archive for History of Exact Sciences 69, no. 1 (2015): 108. 
Kaiyuan zhanjing 開元占經, 105.4a:

上元壬午至今三萬二千七十二算外

$\ldots$ from high origin [in year] renwu. . $_{19}$ to today is 32,072 [years] outside the count (i.e. to be counted exclusively).

Emperor Wen of Wei, cited in Sanguo zhi 三國志, 2.78:

其令百官各虔厥職, 後有天地之致, 勿復劾三公

... [everyone] go sincerely about their own job ... and stop denouncing the Three Excellencies.

Wuxing zhan 五星占, silk MS, Mawangdui tomb 3 (sealed 168 bce):

【進退】無恒, 不可為【極】

... [advancing and retreating] are without constancy (wu heng) and cannot be taken as a [standard]' (line 45)

Li Yexing 李業興 (484-549 CE), cited in Wei shu 魏書, 107B.2698:

熒惑一星，伏見體自無常，或不應度

... the one [planet], [Mars], does not always correspond with the [predicted] $d u$, as its hiding and appearance are inherently lacking any constancy (wu chang).

Hou Han shu 後漢書, zhi 2, 3028:

令兩候, 得等多者

... ordering two watches, wherein the superior would be they who got the most counting rods (suan).

Hou Han shu 後漢書, zhi 2, 3025:

詔書令岑普〔候〕，與官〔曆〕課。起七月，盡十一月，弦望凡 五, 官曆皆失, 岑皆中。庚寅, 詔(書) 令岑署弦望月食官, 復 令待詔張盛、景防、鮑鄴等以四分法與岑課。歲餘，盛等所中多 岑六事。十二年十一月丙子, 詔書令盛、防代岑署弦望月食加時。 An edict [was issued] ordering [Yang] Cen to [conduct] a general watch (hou) and rank (ke) [his system] against the official li. Of a total of five quarter and full moons from month VII to XI the official $l i$ was in each case off target (shi), and Cen was in each case on target (zhong). On gengyin.27, an edict [was issued] ordering Cen to be appointed to the office for quarter and full and lunar eclipses; [it] furthermore ordered expectant appointees Zhang Sheng, Jing Fang, Bao Ye et al. to rank (ke) Cen['s system] against the quarterremainder method. More than one year [later], [the number of] matters where [Zhang] Sheng et al. were on target (zhong) was greater (duo) than Cen by six. On 12-XI-bingzi.13 $(69 \mathrm{CE})$, an edict [was issued] ordering Sheng and Fang to replace Cen in predicting quarter and full, lunar eclipses, and added hours.

Huainan honglie jijie 淮南鴻烈集解, 8.254-5:

逮至堯之時，十日並出，焦禾稼，殺草木……堯乃使羿誅鳌齒于 疇華之野, 殺九嬰于凶水之上, 繳大風於青丘之澤, 上射十日而 下殺猰貐, 斷修蛇於洞庭, 禽封狶于桑林, 萬民皆喜, 置堯以為 天子。 
In the time of Yao, the ten suns rose at once, scorching the stalks and sow and killing the grasses and trees... Yao sent Yi to punish Chisel Tooth in the meadows of Chouhua, to kill Nine Gullet on the banks of the waters Xiong, to snare Typhoon in the wilds of Greenhill, to shoot the ten suns above and kill the Yayu below, to split Long Snake at Cave's Court and to capture Mound Pig in Mulberry Grove - and the myriad people all rejoiced and installed Yao as the son of heaven. ${ }^{19}$

Lingxian 靈憲, cited in Hou Han shu 後漢書, zhi 10, 3216 (comm.):

姮娥窲之以奔月

... [his wife Chang'] stole it and fled to the moon.

Liji zhushu 禮記注疏, 28.534b:

男子生, 桑弧蓬矢六, 以射天地四方。天地四方者, 男子之所有 事也。

When a male child is born, it is [given] a bow of mulberry and six arrows of fleabane by which to shoot heaven, earth and the four directions, [these] being where a man's business lies.

Liji zhushu 禮記注疏, 28.534a:

男子設弧於門左，女子設帨於門右。三日，始負子，男射女否。 ... places a bow to the left of one's door [to announce] the birth of a male child ... and, on the third day, one begins to carry the child on one's back, [going] shooting for a boy, but not for a girl.

Zhouli zhushu 周禮注疏, 10.160b:

六藝, 禮、樂、射、御、書、數

... the six arts: ritual/politeness, music, shooting, driving, writing and numbers.

Jin shu 晉書, 103.2683:

劉曜……身長九尺三寸……雄武過人，鐵厚一寸，射而洞之。

Liu Yao (r. 318-29) was $9^{\text {ch }} 3^{\mathrm{c}}(229 \mathrm{~cm})$ tall ... heroic and martial beyond anyone else, [he] could shoot and pierce through iron one cun $(2.44 \mathrm{~cm})$ thick.

Jin shu 晉書, 102.2657

劉聰……五習擊刺, 猿臂善射, 彎弓三百斤

Liu Cong (r. 310-18)... studied swordsmanship at fifteen, he was an Ape-arm good shot, [his] crossbow [weighing] three-hundred jin $(66 \mathrm{~kg})$.

Hou Han shu 後漢書, 85.2812:

又善射, 發能入人目。

... [so] good at shooting that with [one] release [they can] penetrate a man's eye.

\footnotetext{
${ }^{19}$ Tr. modified from John S. Major, ed., The Huainanzi: A Guide to the Theory and Practice of Government in Early Han China (New York: Columbia University Press, 2010), 275-76.
} 
Shiji 史記, 109.2872 (comm.):

射戲求疏密, 持酒以飲不勝者。

The sport (xi) of shooting looks for looseness and tightness (shu-mi), and one takes alcohol to make the loser drink.

Shiji 史記, 4.165:

楚有食由基者，善射者也。去柳葉百步而射之，百發而百中之。 左右觀者數千人，皆曰善射。

The [Kingdom of] Chu had Yang Youji, who was a good shot. Shooting at a willow leaf from $100 \mathrm{bu}$ (138.6 metres), [he] hit (zhong) it a hundred times out of a hundred releases, [leading] the several thousand observers (guan zhe) to the left and right to all say, '[What] a good shot!'

Han shu 漢書, 51.2360:

楊葉之大，加百中焉

$\ldots$ and for big willow leaves he threw in another hundred hits.

Diwang shiji 帝王世紀, cit. in Taiping yulan 太平御覽, 82.9a:

羿引弓射之誤中右目羿，俯首而愧終身不忘。

Yi ... mistakenly hit (zhong) the right eye; [he] lowered his head from shame and never forgot it till the end of his days.

Huainan honglie jijie 淮南鴻烈集解, 16.529:

善射者發不失的。

A good marksman does not shoot to miss (shi).

Liji zhushu 禮記注疏, 62.1015b:

其容體比於禮，其節比於樂，而中多者，得與於祭。

those who [deliver] the most hits (zhong) with their bodily comportment in conformity with the rites and their rhythm in conformity with the music shall be granted participation in sacrifice.

Liji zhushu 禮記注疏, 62.1017b:

射者各射己之鵠。

Each shooter shoots at the mark of his [ideal] self.

Liji zhushu 禮記注疏, 62.1020a:

射求正諸己, 己正而後發, 發而不中, 則不怨勝己者, 反求諸己 而巳矣。

The shoot[er] seeks correctness in himself. Only after correcting himself does [he] release, and [if he] shoots and misses (bu zhong), then [he] is not angry with the winner but turns around and seeks [the cause of his failure] in himself.

Edsen-gol 45.23

功令第冊五: 候長、士吏皆試射, 射去毫 [巩+巾], 㛎力如發驽, 發十二矢, 中 [巩+巾]矢六為程, 過六, 矢賜勞十五日。 
Proficiency Ordinance no 45. Watch chiefs and gentleman clerks shall all be tested (shi) in archery. [They] shall shoot at targets at a remove from the butt using crossbows with the strength of operational bows. [They] shall release twelve arrows, six [registered] hits on the target being the standard [of proficiency]. If more than six, an award of fifteen days' service shall be granted in respect of each arrow. ${ }^{20}$

Edsen-gol 312.9:

居延甲渠逆胡隧長公乘王冊何, 五鳳元年秋以令射發矢十二中六 當。

Wang Wuhe, grandee of the eighth order, commanding officer of Nihu section, Jiaqu [company], Juyan (Edsen-gol), shot in accordance with the ordinance, in autumn of [57 BCE], releasing twelve arrows and hitting [the target with] six: qualified. ${ }^{21}$

Zhouli zhushu 周禮注疏, 26.403b:

凡射事，飾中，舍算，執其禮事。

$\ldots$ in all matters of shooting, conducts ceremonial matters of proclaiming hits and lodging counting rods.

${ }^{20}$ Tr. modified from Michael Loewe, Records of Han Administration, 2 vols (Cambridge: Cambridge University Press, 1967), vol. 1, 118.

${ }^{21}$ Tr. modified from ibid. 


\section{Chapter 5}

Song shi 宋史, 105.2552:

自昔著名算數者畫像兩庶, 請加賜五等爵, 隨所封以定其服。

Those renowned from the days of yore for calculating numbers (suan shu) have their portraits painted on either corridor. It is requested that [they] be additionally bestowed noble titles of the five ranks and that their clothing be fixed (repainted) in accordance with their enfeoffment.

Zhou Cong 周琮, cited in Song shi 宋史, 75.1738-9:

「古今之曆, 必有術過於前人, 而可以為萬世之法者, 乃為勝也。 若一行為大衍曆議及略例, 校正歷世, 以求曆法強弱, 為曆家體 要, 得中平之數。劉焯悟日行有盈縮之差, 李淳風悟定朔之法, 并氣朔、閏餘, 皆同一術。張子信 悟月行有交道表裏, 五星有入 氣加減。宋何承天始悟測景以定氣序。晉姜苃始悟以月食所衝之 宿, 為日所在之度。後漢劉洪作乾象曆, 始悟月行有遲疾數。宋 祖沖之始悟歲差。唐徐昇作宣明曆，悟日食有氣、刻差數。明天 曆悟日月會合為朔, 所立日法, 積年有自然之數, 及立法推求㟯 景, 知氣節加時所在。後之造曆者, 莫不遵用焉。其疏謬之甚者, 即苗守信之乾元曆、馬重績之調元曆、郭紹之五紀曆也。大概無 出於此矣。

Of the $l i$ of antiquity and today, there are inevitably procedures that surpass (guo) [those of their] predecessors, but only those that can become the model $(f a)$ of a myriad generations are the [real] winners (sheng). Like Yixing (683-727 CE), who, in making [his] deliberation argument (yi) and summary examples for the Great Expansion $l i$, collated and corrected successive generations [of data] in order to find the strengths and weaknesses of [historical] li models $(f a)$, make summaries of [historical] $l i$ lineage experts, and obtain numbers of centre and balance, [so too shall we proceed]. Liu Zhuo awoke to [the realisation] that solar motion experiences a discrepancy of excess and deficit (ying-suo; i.e. inequality), and Li Chunfeng awoke to the model $(f a)$ of fixed syzygy, combining $q i$, syzygy and intercalary remainder this was all the same single procedure. Zhang Zixin awoke to [the realisation] that lunar motion [goes on] a crossed road, inside and outside [the ecliptic], and that the five [planets] have qi-entry addition and diminution (i.e. seasonal corrections for first and last visibility). He Chengtian of the [Liu] Song first awoke to [the idea] of fixing the sequence of $q i$ via the measurement of shadows. Jiang Ji of the Jin first awoke to [the realisation that] the lodge opposite that of lunar eclipse is the $d u$ at which the sun is. Liu Hong of the Later Han created the Supernal Icon $l i$ having first awoken to [the realisation] that lunar motion experiences numbers of slow-fast. Zu Chongzhi of the [Liu] Song first awoke to [the realisation] of the year difference (i.e. precession of the equinoxes) ... There is no latter-day $l i$ creator who does not honour and use these [models]. Those that are profoundly loose and erroneous [today] - namely the Supernal Origin $l i$ of Miao Shouxin $(981 \mathrm{CE})$, the Adjusted Origin $l i$ of Ma Chongxu (938 CE) and the Five-Era li of Guo Shao (762 CE) - do not excel/emerge from $(c h u)$ this.

然造曆者, 皆須會日月之行, 以為晦朔之數, 驗春秋日食, 以明 強弱。其於氣序, 則取驗於傳之南至; 其日行 盈縮、月行遲疾、 五星加減、二曜食差、日宿月離、中星晏景、立數立法, 悉本之 於前語。然後較驗, 上自夏仲康五年九月『辰弗集于房』, 以至 
於今，其星辰氣朔、日月交食等，使三千 年間若應準繩。而有前 有後、有親有疏者, 即為中平之數, 乃可施於後世。

As such, all li creators must tally solar and lunar motion to have the numbers of dark and new moon and [must retrodictively] verify the solar eclipses of the Spring and Autumn Annals (722-481 BCE) to illustrate [their] strength and weakness. As to the sequence of $q i$, one takes verification from the [winter solstice records] of the traditions (of the Spring and Autumn Annals). As to the excess and deficit of solar motion, the slow and fast of lunar motion, the addition and diminution of the five [planets], the eclipse difference of the two luminaries, solar lodges and lunar displacement, meridian stars and gnomon shadows, establishing numbers and establishing models - all of this one roots in former accounts $(y u)$. After that [comes] comparative verification: from all the way up to the 'the chronograms not gathering in Chamber. ${ }_{\mathrm{L} 04}{ }^{22}$ in [King] Zhong Kang of Xia 5-IX down to today, for the [planets], chronograms, $q i$ and syzygies and solar and lunar crossing and eclipse, etc., that one make [everything] within three thousand years align as if by level and plumb, and where one [is] ahead or behind, intimate (qin) or loose (shu), one makes numbers of centre and balance - [only] then can [one's procedures] spread to later generations.

其較驗則依一 行、孫思恭，取數多而不以少，得為親密。較日月 交食，若一分二刻以下為親，二分四刻以下為近，三分五刻以上 為遠。以曆注有食而天驗無食, 或天驗有食而曆注無食者為失。 其 較星度, 則以差天二度以下為親, 三度以下為近, 四度以上為 遠; 其較㫡景尺寸, 以二分以下為親, 三分以下為近, 四分以上 為遠。若較古而得數多, 又近於今, 兼立法、立數, 得其理 而通 於本者為最也。」

One's comparative verification [should be] as per Yixing and Sun Sigong (eleventh century), taking many numbers - not going by few for results that are intimate and tight. In comparing solar and lunar crossing and eclipse, [an error of] 0.12 notch $(1 \mathrm{~m} 44 \mathrm{~s})$ or less is 'intimate'; 0.24 notch $(3 \mathrm{~m} 27 \mathrm{~s})$ or less is 'close'; 0.35 notch $(5 \mathrm{~m} 2 \mathrm{~s})$ or more is 'far'; and if the li notes (predictions) have eclipse, but heaven verifies there is no eclipse, or [vice versa], it is a 'miss'. In comparing [planetary] $d u$, on the other hand, erring from heaven by two $d u$ or less is 'intimate'; three $d u$ or less is 'close'; and four $d u$ or more is 'far' ... The best (zui) is one who gets many of the numbers upon comparison with antiquity and is furthermore close today, establishing a model and establishing numbers upon the two to get at the natural order (li) and penetrate (tong) to [its] root.

Zhou Cong 周琮, cited in Song shi 宋史, 74.1689:

書舉正南之星以正四方, 蓋先王以明時授人, 奉天育物。然先儒 所述, 互有同異。虞喜云: 「堯時冬至日短星昂, 今二千七百餘 年, 乃東壁中, 則 知每歲漸差之所至。」又何承天云:「堯典:

『日永星火, 以正仲夏; 宵中星虛, 以正仲秋。』今 以中星校之, 所差二十七八度, 即堯時冬至, 日在須女十度。」故祖沖之修大 明曆, 始立歲差, 率四十五年九月却一度。

The Documents raises the due-south stars (meridian stars) for rectifying the four directions, [this] being what the former kings used to elucidate the seasons and grant [them] to people, to serve heaven and nurture [the myriad living] things. However, the accounts of

${ }^{22}$ Citing Shangshu zhushu, 7.102b. Later commentary to this passage in the Documents glosses 'the chronograms not gathering' as a solar eclipse. 
former scholars have similarities and differences between them. Yu Xi says: 'In the time of Yao, on the winter solstice.Q22 - shortest day - the star was Mane.L18; now, after 2,700-odd years, Eastern Wall. ${ }_{\text {L14 }}$ is centred, which [we] know was arrived at by gradual difference every year'. Moreover, He Chengtian says: ... 'By comparison with the centred star of today, the difference is twenty-seven or eight $d u$, i.e. on winter solstice. ${ }_{\mathrm{Q} 22}$ in the time of Yao the sun was at Maid. ${ }_{\mathrm{L} 10} 10 d u$ '. Thus, when $\mathrm{Zu}$ Chongzhi made the Grand Enlightenment $l i$, he first established the annual difference, [his] lü-rate forty-five years and nine months per $d u$ of retreat.

Shuowen jiezi zhu 說文解字注, 3A.7a:

三十年爲一世

... thirty years makes one 'generation' (shi)

Cai Yong 蔡邑 (133-92 CE), cited in Hou Han shu 後漢書, zhi 2, 3038:

今〔術)之不能上通於古, 亦猶古術之不能下通於今也。

... today's procedures cannot tong up to antiquity any more than ancient procedures can tong down to today.

Du Yu 杜預 (222 - 85 CE), cited in Jin shu 晉書, 18.563-4:

余感春秋之事, 嘗著曆論, 極言曆之通理。其大指曰: 天行不息, 日月星辰各運其舍, 皆動物也。物動則不一, 雖行度有大量可得 而限, 累日為月, 累月為歲, 以新故相涉, 不得不有毫末之差, 此自然之理也……

In touching upon the events in the Spring and Autumn Annals, I once composed a $l i$ discourse as a culmination of talk about the tong principles $(l i)$ of $l i$. The gist was this: heaven's motion never ebbs, and the sun, moon and [planets] each revolve [through] their lodges - all of these are moving things. The motion of things, however, is not one [and the same], [so] while [their] motion $d u$ can be in large part successfully delimited, as the days pile into months, and as the months pile into years, there is inevitably a difference (cha) of a hair's end in invoking the new against the old - this is a principle that is such in and of itself ...

余為曆論之後, 至咸寧中, 善算者李修、卜顯, 依論體為術, 名 乾度曆, 表上朝廷。其術合日行四分數而微增月行, 用三百歲改 憲之意, 二元相推, 七十餘歲, 承以強弱, 強弱之差蓋少, 而適 足以遠通盈縮。時尚書及史官, 以乾度與泰始曆參校古今記注, 乾度曆殊勝泰始曆, 上勝官曆四十五事。今其術具存。又并考古 今十曆以驗春秋, 知三統之最疏也。

After I made [this] $l i$ discourse, in [275-80 CE], the expert calculators $\mathrm{Li} \mathrm{Xiu} \mathrm{and} \mathrm{Bu} \mathrm{Xian} \mathrm{made} \mathrm{procedures} \mathrm{according} \mathrm{to} \mathrm{the} \mathrm{discourse} \mathrm{body,}$ which was named the Supernal Degree $l i$ and memorialised to the court. The procedures ... invoked the intention of 'changing constitutions every 300 years' [by] calculating with two different origins and multiplying by strong and weak (?) every seventy-odd years, the strong and weak difference being small but just enough to tong from afar [any] excess and deficit. At the time, the Masters of Writing, as well as the Clerk's Office, referenced and compared the Supernal Degree and Grand Beginning li (a.k.a. Luminous Inception li) against records and notes from antiquity and today, and the Supernal Degree $l i$ scored an outstanding win over the Grand Beginning $l i$, 
winning over the official $l i$ above (in antiquity) on forty-five items. These procedures are both extant today, and when one combines [them] to investigate the ten $l i$ of antiquity and today in verifying the Spring and Autumn Annals, one [can] know the eminent looseness of the Triple Concordance (c.5 CE).

Jiang Ji 姜苃 (fl. 384 CE), cited in Jin shu 晉書, 18.567:

春秋之世, 下至於今, 凡一千餘歲, 交會弦望故進退於三蝕之間, 此法迺可永載用之, 豈三百歲斗曆改憲者乎?

[From] the age of the Spring \& Autumn Annals down to today $(384 \mathrm{CE})$, a total of one-thousand-odd years [have elapsed], and crossing and coincidence and quarter and full [moon] thus advance and retreat between three eclipses (?).This model can be used for a long/eternal [number] of years (yong zai), so what of this 'reforming the constitution of the Dipper li every 300 years'?

Xin Tang shu 新唐書, 31.805:

至於後世, 其法漸密者, 必積眾人之智, 然後能極其精微哉。

As one proceeds to later ages, the methods $(f a)$ become gradually tighter. [This is because] it is necessary to accumulate (ji) the knowledge of many people before it is possible to reach the ultimate in fineness and subtlety. ${ }^{23}$

Yuan shi 元史, 52.1130:

惟其所差至微, 前人初未覺知。

... it is only that that the difference is so supremely minute that [our] predecessors were not at first yet conscious [thereof]. ${ }^{24}$

Song shu 宋書, 11.205-6:

元嘉中, 東海何承天受詔纂宋書, 其志十五篇, 以續馬彪漢志, 其證引該博者, 即而因之, 亦由班固、馬遷共為一家者也。其有 漏閲, 及何氏後事, 備加搜采, 隨就補綴焉。

In [424-53 CE], He Chengtian of Donghai received an edict to compile the monographs, in fifteen chapters, of a Book of Song so as to continue [Si]ma Biao's (c.237-306 CE) monographs of the [Later] Han (25-220 CE). The comprehensiveness and breadth of its evidence and citations [are why I] have gone to and followed them and also what places [He Chengtian] alongside Ban $\mathrm{Gu}(32-92 \mathrm{CE})$ and [Si]ma Qian (c.145-c.86 BCE) as a single expert lineage (of historiography). Where there are omissions and elisions, and were we come to events after $\mathrm{Mr} \mathrm{He},[\mathrm{I}]$ patch things up as [I] go by supplying what [I myself] have gathered.

Song shu 宋書, 23.673:

始推渾天意。

... first calculated the sphere heaven idea.

Wang Fan 王蕃 (228-66 CE), cited in Song shu 宋書, 23.677:

\footnotetext{
${ }^{23}$ Tr. modified from Henderson $(2006,100)$.

${ }^{24}$ Tr. modified from Henderson $(2006,101)$.
} 
鄭玄有贍雅高遠之才, 沈靜精妙之思, 超然獨見, 改正其說, 聖 人復出, 不易斯言矣

Zheng Xuan had talent in abundance, elegance, height, and reach and thinking of depth, calm fineness and subtlety - overtakingly, with [his] unique insight, did [he] correct [his predecessors'] explanations. The sage emerges once again, there is no changing his words.

Hou Han shu 後漢書, 59.1898:

作渾天儀。

... [Zhang Heng] zuo (created/invented) the sphere heaven sight.

Xu Yuan 徐爱 (395-475 CE), cited in Song shu 宋書, 23.678:

故知自衡以前, 未有斯儀矣……偏信無據，未可承用……北斗七 星…...

... one knows therefore that there was not yet such a sight prior to [Zhang] Heng. ... prejudiced belief without evidence not to be taken for granted... the seven stars of the Northern Dipper (UMa)...

Song shu 宋書, 23.678:

以此而推, 則西漢長安已有其器矣。將由喪亂亡失, 故衡復鑄之 乎?

Deducing from this, Western Han Chang'an already had the apparatus. This would have went missing amid the death and chaos [of the Wang Mang interregnum (9-23 CE)], thus [Zhang] Heng was [simply] recasting it!

Song shu 宋書, 23.679:

蓋天之術, 云出周公旦訪之殷商, 蓋假託之說也。其書號曰周髀。 髀者表也。周天之數也

The procedures of umbrella heaven are said to have emerged from Duke Dan of Zhou's (r. 1042-1036 BCE) visit to the Yin-Shang, but this is due to false attribution; the book is called Zhou bi, bi meaning 'gnomon', and zhou 'the number of the circumference of heaven'. ${ }^{25}$

Song shu 宋書, 23.679:

好異者之所作也。

the creation of those fond of oddities (yi).

Song shu 宋書, 23.680:

凡三說皆好異之談, 失之遠矣。

These three explanations are all [nothing but] curious chatter and miss the mark by a great distance.

Jin shu 晉書, 11.278; Sui shu 隋書, 19.505:

其本庖犧氏立周天曆度, 其所傳則周公受於殷高, 周人志之, 故 曰周髀。

Its origins [began] with [Fu]xi's establishment of the li $d u$ of the circuits of heaven, and its transmission [began] with the Duke of Zhou

${ }^{25}$ Cf. Zhoubi suanjing, 1.38a, tr. Cullen $(1996,179)$. 
receiving [it] from Yin Gao; men of Zhou made a treatise of it, which is why it is called the Zhou bi. ${ }^{26}$

Jin shu 晉書, 11.279; Sui shu 隋書, 19.506:

天形南高而北下……天之形如倚蓋。

As to heaven's shape, south is high, and north is down... the shape of heaven is like an inclined umbrella. ${ }^{27}$

Sui shu 隋書, 19.507:

其後桓譚、鄭玄、蔡邑、陸績, 各陳周髀考驗天狀, 多有所違。 逮梁武帝於長春殿講義, 別擬天體, 全同周髀之文, 蓋立新意, 以排渾天之論而已。

The later [attempts of] Huan Tan (c.43 BCE-28 CE), Zheng Xuan, Cai Yong and $\mathrm{Lu} \mathrm{Ji}$ to each to examine and verify heaven's shape via exposition of the Gnomon of Zhou were largely contradictory. And then [we] come to Liang Wudi's speech at the Hall of Eternal Spring: [he] dreamt up his own heaven's form (cosmology), which was completely the same as the text of the Gnomon of Zhou, for the sole purpose, probably, of establishing [some] fresh idea to dismiss the discourse on sphere heaven.

Jin shu 晉書, 11.279; Sui shu 隋書, 19.507:

漢祕書郎郗萌記先師相傳

... Han Gentleman of the Palace Library Xi Meng's record of the transmission of its first master(s). ${ }^{28}$

Jin shu 晉書, 11.280; Sui shu 隋書, 19.508:

自虞喜、虞篮、姚信皆好奇徇異之說，非極數談天者也。

From Yu Xi, Yu Song and Yao Xin [on], everything is whimsical and fantastical explanations, these are not people who discussed heaven by plumbing the numbers. ${ }^{29}$

Jin shu 晉書, 11.280:

至於渾天理妙，學者多疑。

Many scholars were dubious when faced with the subtle principles of sphere heaven ${ }^{30}$

Jin $s h u$ 晉書, 11.284:

此則儀象之設, 其來遠矣。緜代相傳, 史官禁密, 學者不覩, 故 宣、蓋沸騰。

This, then, was the institution of the sight-effigy, its origins going back a long way. [This] was handed down through [each] continuous age, [but access to] the Clerk's Office was tightly forbidden, and

${ }^{26}$ Cf. Ho $(1966,49)$.

${ }^{27}$ Cf. Ho $(1966,51-2)$.

${ }^{28}$ Cf. Ho $(1966,52)$.

${ }^{29}$ Cf. Ho $(1966,53-4)$.

${ }^{30}$ Cf. Ho (1966, 54-5). 
scholars did not see [it], and thus did expansive [night] and umbrella [heaven] roil in competition. ${ }^{31}$

Sui shu 隋書, 19.516:

載筆之官, 莫之或辨。史遷、班固, 猶且致疑。馬季長創謂璣衡 為渾天儀。....今案虞喜云: 「落下閞為漢孝武帝於地中轉渾天, 定時節，作泰初曆。」或其所製也。

No brush-toting official (historian) ever makes the distinction. [Grand] Clerk [Sima] Qian and Ban Gu cast the matter into particular doubt (by explicitly identifying it with Northern Dipper), Ma [Rong] being the first to conceive of saying that [xuanji] yuheng was the sphere heaven sight ... Today [I] note: Yu Xi says, 'Luoxia Hong turned the sphere heaven at the centre of the earth for Emperor Xiaowu of Han, fixing the seasonal nodes and creating the Grand Inception $l i$ ' - [it] was probably his creation.

Sui shu 隋書, 19.512:

舊說渾天者, 以日月星辰，不問春秋冬夏，書夜晨昏，上下去地 中皆同, 無遠近。

Old (jiu) explanations of sphere heaven relied on the sun, moon and stars; [they] did not inquire into [the seasons], [the sun's diurnal motion], nor whether the centre of the earth is the same distance from zenith and nadir, without [one] being further or closer [than the other].

Zu Geng 祖恒 (fl. 504-25 CE), cited in Sui shu 隋書, 19.514:

自古論天者多矣, 而㸷氏糾紛, 至相非毀。竊覽同異, 稽之典經, 仰觀辰極, 傍矚四維, 覩日月之升降, 察五星之見伏, 校之以儀 象, 覆之以㟯漏, 則渾天之理, 信而有徵。輙遺眾說, 附渾儀云。 考靈曜先儒求得天地相去十七萬八千五百里, 以暑影驗之, 失於 過多。既不顯求之術, 而虛設其數, 蓋夸誕之辭, 宜非聖人之旨 也。學者多固其說而未之革, 豈不知尋其理歟, 抑未能求其數故 也?

Since antiquity, there have been many who have discoursed upon heaven, but the big names all disagree to the point of mutual destruction. I have humbly reviewed their differences, investigated the matter in the classics, looked up to observe (guan) the [stars] and pole, gazed out at the four corners (of the earth), perceived the rise and fall of sun and moon, inspected the appearance and hiding of the five [planets], checked it by means of sight and effigy, re-examined it by means of gnomon and [water clock], and [I can tell you that] the principles (li) of spherical heaven are credible and evidenced (xin er youzheng). [I] shall thus toss out the diverse explanations [of my predecessors] and stick to the sphere sight. From the [weft text] Kao ling yao, former scholars arrived at the figure of 178,500 li for the distance between heaven and earth, [but] when verified by means of gnomon shadows it misses the mark in excess. Rather than reveal its procedure for attaining [this figure], [the Kao ling yao] emptily posits the number - probably just an expression of exaggerated nonsense - which is certainly not the directive of the sages. Most scholars hold stubbornly to this explanation without changing it - do [they] not know to seek out its principles, or that the reason for this number cannot be sought? Wang Fan's investigation, when compared to previous opinions, reduced [this figure] by no less than one-half. It

${ }^{31}$ Cf. Ho $(1966,59)$. 
was not something that [he] knew from observation (kui) but that [he] sought out [only] through reasoning (li), and thus [he] was truly unable to get at the substance of the matter from afar. Even so, might not [he] have been close and tight?

Song shu 宋書, 12.231-2:

光和中, 穀城門候劉洪始悟四分於天疏闊, 更以五百八十九為紀 法, 百四十五為斗分, 造乾象法, 又制遲疾曆以步月行。方於太 初、四分, 轉精微矣。

In [178-84 CE], Watchman of the Wall at Gucheng Gate Liu Hong first awoke [to the realisation] that the Quarter-remainder [li] was loose and wide of heaven. [He] changed the era divisor to 589, and the Dipper parts to 145, and [he] created the Supernal Icon method. [He] furthermore formulated the slow-fast $l i$ to pace lunar motion, and only with this was there finally a turn towards the fine and subtle relative to the Grand Inception and Quarter-remainder.

魏文帝黃初中, 太史丞韓靖以為乾象減斗分太過, 後當先天, 造 黃初曆, 以四千八百八十三為紀法, 一千二百五為斗分。其後尚 書令陳最奏, 以為「曆數難明, 前代通儒多共紛爭。

In [220-6 CE], Assistant to the Grand Clerk Han Yi thought that the Supernal Icon $l i$ went too far in reducing the Dipper parts and that it would later slip ahead of heaven, so [he] constructed the Yellow Inception $l i$, using an era factor of 4,883 and a Dipper parts of 1,205. Later, Prefect of the Masters of Writing Chen Qun (d. $237 \mathrm{CE}$ ) submitted a petition, which went: [Petition omitted, see Section 4.1.2 above]. The petition was approved.

明帝時, 尚書郎楊偉制景初曆, 施用至于晉、宋。古之為曆者, 鄧平能修舊制新, 劉洪始減四分, 又定月行遲疾, 楊偉煁酌兩端, 以立多少之衷……此三人, 漢、魏之善曆者。然而洪之遲疾, 不 可以檢春秋, 偉之五星, 大乘於後代, 斯則洪用心尚疏, 偉拘於 同出上元壬辰故也。

In [226-39 CE], Master of Writing Yang Wei formulated the Luminous Inception $l i$, which was used all the way into the Jin and [Liu] Song. As to the $l i$-workers of antiquity, Deng Ping was able to repair the old and formulate the new, Liu Hong was first to diminish the Quarter-remainder (Dipper parts) and also to fix lunar motion slow-fast, and Yang Wei weighed both sides ... These three men were li experts of the Han and [Cao] Wei. Even so, Hong's slow-fast did not check out against the Spring and Autumn Annals, and Wei's five [planets] were largely contrary in later ages - the reason for this being that Hong's presence of mind was still loose, and that Wei restricted himself to everything emerging at a high origin of renchen.29.

Wuyingdian ben ershisan shi kaozheng, 34.13a:

劉焯所造《皇極曆》，隋世並未施行，即唐初傅仁均造戌寅曆， 亦但祖述張贵玄成法, 未嘗用焯所定。而此志空存其說, 別為一 卷, 猶《晉志》於乾象、黃初二曆之後附以姜峎所造三紀甲子元 曆。

The Sovereign Pole $l i$ created by Liu Zhuo was never instituted in Sui times (581-618 CE), and when Fu Renjun (fl. $618 \mathrm{CE}$ ) created the Wuxin. $_{15} l i$ in the early Tang, [he] adhered to Zhang Zhouxuan's successful model (cheng $f a$ ) as his sole ancestor, making no use whatsoever of what Zhuo had set down. However, this (the Book of Sui) monograph vacuously (kong) preserves his [work], devoting one 
separate fascicle [thereto]. [This] is like how the [Book of] Jin monograph appends the Triple-era Jiazi.01-origin $l i$ created by Jiang Ji after the Supernal Icon and Yellow Inception $l i$.

Song shu 宋書, 12.231:

何承天曰: 夫曆數之術, 若心所不達, 雖復通人前識, 無救其為 䊂也。是以多歷年歲, 未能有定。四分於天, 出三百年而盈一日。 積代不悟, 徒云建曆之本, 必先立元, 假言讖緯, 遂關治亂, 此 之為蔽, 亦已甚矣。劉歆三統法尤復疏闊, 方於四分, 六千餘年 又益一日。揚雄心惑其說, 采為太玄, 班固謂之最密, 著于漢志; 司彪因曰「自太初元年始用三統曆, 施行百有餘年。」曾不憶劉 歆之生, 不逮太初, 二三君子言曆, 幾乎不知而妄言歟。

He Chengtian says: 'As to the procedures of $l i$ numbers, if one's mind does not understand, then even if one has mastered others' previous knowledge, one will have no way to save it from their faults. This is why nothing has yet to be settled over the course of so many years. In heaven, the Quarter-remainder produces one day in excess every three hundred years. The accumulated ages did not awaken, vainly saying "the root to establishing $l i$ is the necessity of first establishing the origin" with spurious words of prophecy and weft [literature that they] then connected to order and chaos - this is a fault, and [it] is a sufficiently profound one at that. Liu Xin's Triple Concordance method was particularly loose and wide, adding yet another day every six thousand-plus years over the Quarter-remainder. Yang Xiong's mind was confused by [his] theory, adopting [it] for the [Classic of] Supreme Mystery; Ban Gu referred to it as "superlatively tight", writing [it] into the [Book of] Han monographs; Si[ma] Biao followed up with, "From first implementation in Grand Inception 1 (104 BCE), the Triple Concordance $l i$ was in effect for more than a hundred years." Not remembering that Liu Xin had yet to be born by the Grand Inception [period] (104-101 BCE), when these gentlemen speak of $l i$, [they] speak foolishly out of near [total] ignorance'.

Jin $s h i$ 金史, 22.523 :

等器久皆棄毀……渾儀仆落臺下……以渾儀鎔鑄成物。

... various apparatus having been long discarded and destroyed... the sphere sight lurched and fell off the terrace... melted the sphere sight down and cast it into [other] things.

Jin shu 晉書, 17.498:

其後劉㰴更造三統, 以說左傳, 辯而非實, 班固惑之, 采以為志。 ...及光和中, 乃命劉洪、蔡邑共修律曆, 其後司馬彪因之, 以繼 班史。今采魏文黃初已後言曆數行事者, 以續司馬彪云。

Liu Xin constructed the Triple Concordance to explain the Zuo Tradition [of the Spring and Autumn Annals], which, upon analysis, was not solid/true (shi); Ban Gu was fooled by it and selected [it] for [his] monograph ... In [178-84 CE], Liu Hong and Cai Yong were ordered to co-operate on the compilation of [a] lü-li [monograph], which Sima Biao later used in following up Ban [Gu]'s history. Here [I] select words on past matters of li numbers from Emperor Wen of Wei's Yellow Inception [reign] (220-6 CE) on so as to continue from Sima Biao['s Book of Later Han] as follows. ${ }^{32}$

${ }^{32}$ Cf. Ho (1966, 45-9). 
Han shu 漢書, 21A.955:

刪其偽辭，取正義，著于篇。

... excised of its more spurious phrasing, taking [its] correct meaning and writing it into a piece.

Sui shu 隋書, 19.518:

而宋御史中丞何承天及太中大夫徐爱, 各著宋史, 咸以為即張衡 所造。其儀略舉天狀, 而不経經星七曜。魏、晉喪亂, 沉沒西戎。 義熙十四年, 宋高祖定咸陽得之。梁尚書沈約著宋史, 亦云然, 皆失之遠矣。

Song Palace Aid to the Censor-in-chief He Chengtian and Superior Grand Master of the Palace Xu Yuan each wrote a history of the [Liu] Song wherein both took [the Kong Ting armillary sphere of $323 \mathrm{CE}$ ] as Zhang Heng's construction ... Liang Master of Writing Shen Yue wrote a history of the [Liu] Song which also says as much - all of them miss the mark by a great distance.

Sui shu 隋書, 19.515-16:

故春秋文耀鉤云：「唐堯即位，羲、和立渾儀。」而先儒或因星 官書, 北斗第二星名姃, 第三星名璣, 第五星名玉衡, 仍七政之 言, 即以為北斗七星。載筆之官, 莫之或辨。史遷、班固, 猶且 致疑。馬季長創謂璣衡為渾天儀。

The Spring and Autumn [weft] Wen yao gou says: 'When Yao of Tang took the throne, the Xi and He [brothers] established the sphere sight'. However, some former scholars followed the star office books, [which state that] the Northern Dipper's second star is named 'Turner' (Xuan, $\beta$ UMa), its third star is named 'Mechanism' (Ji, $\gamma \mathrm{UMa})$, its fifth star is named 'Jade Traverse' (Yuheng, $\varepsilon \mathrm{UMa}$ ), and thus that the talk about 'seven governors' [in the Book of Documents refers to] none other than the seven stars of the Northern Dipper. No brush-toting official (historian) ever makes the distinction, even though Clerk [Sima] Qian and Ban Gu cast [the matter] in doubt.

Baopuzi waipian jiaojian, 50.698:

其《內篇》言神仙方藥、鬼怪變化、養生延年、禳邪卻禍之事, 屬道家; 《外篇》言人間得失, 世事藏否, 屬儒家。

In the 'Inner Chapters', [I] speak of such matters as the recipes and drugs of gods and immortals, the marvels and metamorphoses of ghosts and monsters, the extension of years via the nourishment of life, and the avoidance of disaster via the exorcism of evil - that belonging to the dao expert lineage (dao jia); in the 'Outer Chapters', [I] speak of success and failure among men and the goodliness or not of worldly matters - that belonging to the scholastic/Confucian expert lineage (ru jia).

\section{Baopuzi waipian jiaojian, 50.656:}

不喜星書及算術九宮三棋太一飛符之屬, 了不從焉。由其苦人而 少氣味也。

[I] disliked star books as well as mathematical procedures ... and the like, [so I] was unable to follow - it was because they were hard on a person while at once lacking in interest. 
Ge Hong 葛洪 (283-343 CE), cited in Jin shu 晉書, 11.281-2; cf. Sui shu 隋書, 19.509-10:

渾天儀注云: 「天如鷄子, 地如鷄中黃, 孤居於天內, 天大而地 小。天表裏有水, 天地各乘氣而立, 載水而行。周天三百六十五 度四分度之一, 又中分之, 則半覆地上, 半繞地下, 故二十八宿 半見半隱, 天轉如車轂之運也。」

[Zhang Heng's] Sphere Heaven Sight with Commentary states: 'Heaven is like a chicken egg: earth is like the yolk, dwelling alone within heaven; and heaven is big while earth is small. Without and within heaven is water, heaven and earth each riding on qi for support and [one/both?] moving upon the water. The circuit of heaven is $365 d u$ and $1 / 4 d u$, which, moreover, is divided at [its] centre, half above, covering earth, and half below, encircling earth. Thus are the twenty-eight lodges half visible and half hidden [at any given time], heaven turning like the revolution of a wheel hub.'

諸論天者雖多, 然精於陰陽者少。張平子、陸公紀之徒，咸以為 推步七曜之道, 以度曆象昏明之證候, 校以四八之氣, 考以漏刻 之分, 占㫡景之往來, 求形驗於事情, 莫密於渾象者也。張平子 既作銅渾天儀於密室中以漏水轉之，令伺之者閉戶而唱之。其伺 之者以告靈臺之觀天者曰: 「璇璣所加, 某星始見, 某星已中, 某星今沒」, 皆如合符也。崔子玉為其碑銘曰: 「數術窮天地, 制作侔造化, 高才偉藝, 與神合契。」蓋由於平子渾儀及地動儀 之有驗故也。

There are many who discourse upon heaven, yet few who are refined in [matters of] yin and yang. Students of Zhang [Heng] and Lu [Ji] all pursue the dao of calculating the paths of the seven luminaries, $l i$-ing and xiang-ing proven observations (zheng hou) of dusk and dawn with $d u$, comparing with the $q i$ of four and eight (indicator arrows?), examining with the fractions of the leak notch, divining the coming and going of gnomon shadows and seeking the shape [of heaven] in the truth of the matter (shi qing) - [for this] nothing is tighter ( $m i$ ) than the sphere effigy. Zhang [Heng] created a bronze sphere heaven sight in a sealed-tight (mi) room, turned by leak water, ordering its attendant to shut the doors and sing it out. Its attendant announced to the observer(s) of heaven (guan tian zhe) of the Numinous Terrace, 'at [some] add[ed hour] (?) of the xuanji, such-and-such star is first visible, such-and-such star is already centred (culminated), and suchand-such star is currently setting' - all of which were like matching [the two halves of] a tally. [The famous calligrapher] Cui Ziyu (77$142 \mathrm{CE}$ ) wrote the epitaph on his tombstone, which went: '[His] numbers and procedures (shushu) excelled heaven and earth, [his] construction and invention matched Creation itself, [his] tall talent and extraordinary art matched tallies with the gods' - a fact $(g u)$ proven (you yan) by [Heng's] sphere sight and seismoscope.

若天果如渾者, 則天之出入行於水中, 為的然矣。故黃帝書曰, 「天在地外, 水在天外」, 水浮天而載地者也。又易曰: 「時乘 六龍。」夫陽爻稱龍, 龍者居水之物, 以喻天。天, 陽物也, 又 出入水中, 與龍相似, 故以龍比也。聖人仰觀俯察, 審其如此, 故晉卦坤下離上, 以證日出於地也。又明夷之卦離下坤上, 以證 日入於地也。需卦乾下坎上, 此亦天入水中之象也。天為金, 金 水相生之物也。天出入水中, 當有何損, 而謂為不可乎?

If heaven is indeed like the sphere, then the [risings] and [settings] of heaven must really (di ran) move through water. Thus does the Book of the Yellow Emperor state that 'beyond earth is heaven, and beyond heaven is water' - water being what floats heaven and carries earth. 
Moreover, the [Book of] Changes states that '[they] seasonally mount the six dragons' (Qian - yang lines are called 'dragons', dragons are things that dwell in water, as a metaphor for heaven; heaven is a yang thing, and [it] furthermore exits and enters water, which is similar to dragons, thus is it compared with dragons. The sages looked up to observe and down to inspect, and [they] scrutinised that this is how it was. Thus in the Jin hexagram is Kun $\mathbf{E}$ (: earth) below and $\mathrm{Li}$ 王 (: fire) above so as to prove (zheng) that the sun emerges from the earth; [thus], moreover, in the hexagram of Mingyi 兲琶 is Li $\mathbf{I}$ below and Kun above so as to prove that the sun enters into the earth. The Xu hexagram has Qian 三 (: heaven) below and Kan 플 (: water) above, this also being an effigy/sign (xiang) of heaven entering water. Heaven is [the agent] metal, and metal and water are things that mutually generate, [so] what possible damage could it cause heaven to exit and enter the water to make one say that [it] cannot? $?^{33}$

Baopuzi waipian jiaojian, 3.129:

瞻離畢而分陰陽之候, 由冬虫而覺閏余之錯, 何神之有? 學而已 矣。

To distinguish the signs of yin and yang by gazing in the distance at

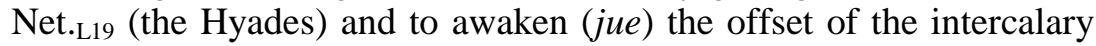
remainder from [the stirrings of] winter insects - what divinity (shen) is there in this? It is only study (xue). ${ }^{34}$

\section{Baopuzi waipian jiaojian, 30.78:}

若舟車之代步涉, 文墨之改結繩, 諸後作而善於前事, 其功業相 次千萬者, 不可復縷舉也。世人皆知之, 快於显矣, 何以獨文章 不及古邪?

It is like how boats and carts substituted walking and fording, and how writing and ink replaced knots and ropes (khipu) - the one is a later invention, but better than the previous thing, the threads its achievements running in the thousands of myriads, this way and that, [such that] they cannot be undone. The people of [this] age all know that [things] are happier (kuai) than in the past, [so] how could it that be [modern] writings alone fall short of antiquity? ${ }^{35}$

\section{Baopuzi neipian jiaoshi, 12.224:}

若仙必可得, 聖人已修之矣, 而周孔不為之者, 是無此道可知也。 If immortality (xian) is necessarily attainable, [then] the sages [would have] already practised it, [so] one knows from [the Duke of] Zhou and [Master] Kong's not having done it that there is no such dao.

\section{Baopuzi neipian jiaoshi, 12.227:}

世人謂聖人從天而墜, 神靈之物, 無所不知, 無所不能。甚於服 畏其名, 不敢復料之以事, 謂為聖人所不為, 則人無復能之者也; 聖人所不知, 則人無復知之者也, 不可笑哉? 今具以近事校之, 想可以悟也。

The people of [this] age say that the sages fall from heaven, that they are divine and numinous beings, and that there is nothing they do not

\footnotetext{
${ }^{33}$ Tr. modified from Ho $(1966,55-6)$.

${ }^{34}$ Tr. modified from Puett $(2007,105)$.

${ }^{35}$ Tr. modified from Puett $(2007,108)$.
} 
know, and nothing they cannot [do]. [So] profound is [their] obeisance and awe of their names [that they] do not dare to go back and assess them with regard to events. [They] say that what the sages did not do, no man will ever be able to do; that what the sages did not know, no man will ever know - isn't that a laugh?! [If], in the here-and-now, one compares (jiao) them against recent events, [I] think one can awaken $(w u){ }^{36}$

Jiu Tang shu 舊唐書, 191.5112:

博覽經史，尤精曆象、陰陽、五行之學。

... widely read in the classics and histories and particularly gifted in the studies of $l i$ and xiang, yin and yang, and the five agents.

Mahāvairocana sūtra (T no. 848, 18: 1b-c):

謂如實知自心……佛言菩提心爲因。悲爲根本。方便爲究竟。

... knowing one's own mind as it truly is... is rooted in compassion, caused by the bodhi-mind, and completed in skilful means.

Yixing 一行 (683-727 CE), cited in Xin Tang shu 新唐書, 27A.596:

則聖人且猶不質, 非籌曆之所能及矣……昔人考天事, 多不知定 朔。

The sages had yet to pose the question, [since] it was something at which [their] li calculations could not arrive. ... [So] when ancient people examined heavenly matters, most of them did not know about fixing the syzygy.

Yixing 一行 (683-727 CE), cited in Xin Tang shu 新唐書, 27A.596-7:

綜近代諸曆，以百萬為率齊之，其所差，少或一分，多至十數失 一分。考春秋總差一刻, 而百數年間不足成朓朒之異。施行未幾, 旋復疎闊, 由未知䠛離經朔相求耳。李業興、甄㝈等欲求天驗,

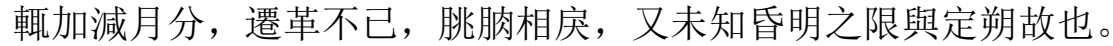
楊偉採乾象為遲疾陰陽曆, 雖知加時後天, 蝕不在朔, 而未能有 以更之也。

To summarise the various $l i$ of the recent age (seventh century), levelling them at a $l \ddot{u}$ of $1,000,000$, their errors are, at the lowest, sometimes one part, and, at the highest, a miss of one part per ten numbers (?). In examination of the Spring and Autumn Annals [they] only erred a notch $(14 \mathrm{~m} 24 \mathrm{~s})$, which would hardly amount to a difference of [a day] over a hundred and something years; shortly after implementation, [however], they soon proved loose and wide, because they had yet to learn (wei zhi) about seeking the step and distance mean syzygy from one another (i.e. the iterative correction of true solar and lunar position). Li Yexing, Zhen Luan et al. (sixth century) desired to seek heavenly verification, [but they] simply added and diminished the lunar fraction, shifting and changing [it] incessantly, breaching [one-day errors] back and forth - [this] again was because [they] had yet to learn (wei zhi) dusk and dawn limit on fixed syzygy. Yang Wei (third century) appropriated the Supernal Icon for the slowfast and yin-yang sequences (i.e. lunar speed and latitude corrections), and though [he] knew that the added hour was behind heaven, and that the eclipse was not on new moon, [he] was as yet unable (wei neng) to do anything to change it.

${ }^{36}$ Tr. modified from Puett $(2007,103)$. 
Yixing 一行 (683-727 CE), cited in Xin Tang shu 新唐書, 27A.598:

考漢元光已來史官注記, 日蝕有加時者凡三十七事, 麟德曆得五, 開元曆得二十二。

Upon examination of the Clerk's Office's note records from [134 BCE] on, there being a total of thirty-seven instances of solar eclipse with added hour, [Li Chunfeng's] Unicorn Virtue $l i$ gets five, and [Yixing's] Kaiyuan $l i$ gets twenty-two.

Mahāvairocana sūtra (T no. 848, 18: 3b):

復次祕密主。大乘行。發無縁乘心。法無我性。何以故。如彼往 昔如是修行者。觀察䋹阿頼耶。知自性如幻陽焰影響旋火輪乾䦮 婆城祕密主。彼如是捨無我。心主自在覺自心本不生。何以故。 祕密主。心前後際不可得故。如是知自心性。是超越二劫瑜祇行。 Next, Lord of Mysteries, there is the practice of the Great Vehicle, whereby one generates the mind of the vehicle without any object [of cognition] and [understands] that dharmas have no self-nature. How? Just like those who practiced thus in former times, one observes (guan cha) the alaya (substratum) of the aggregates and realizes that its own-nature is like an illusion, a mirage, a reflection, an echo, a whirling wheel of fire, and an [imaginary] gandharva city. Lord of Mysteries, if one thus abandons no-self [in dharmas], the mind-lord being absolutely free, one awakens (jue) to the fact that one's own mind is originally unborn. Why? Because, Lord of Mysteries, the anterior and posterior limits of the mind cannot be apprehended. When one thus knows the nature of one's own mind, this represents the yogin's practice for transcending a second eon.

復次祕密主。眞言門修行菩薩行諸菩薩。無量無數百千俱胝那多 劫。積集無量功徳智慧。具修諸行無量智慧方便。皆悉成就。天 人世間之所歸依。出過一切聲聞辟支佛地。釋提桓因等。親近敬 禮。所謂空性。離於根境。無相無境界。越諸戲論。等虚空無邊 一切佛法。依此相續生。離有爲無爲界。離諸造作。離眼耳鼻舌 身意。極無自性心生。祕密主如是初心。佛説成佛因故。於業煩 惱解脱。而業煩惱具依。世間宗奉常應供養。

Next, Lord of Mysteries, bodhisattvas cultivating bodhisattva practices via the gateway of mantras accomplish all the immeasurable merit and knowledge accumulated during immeasurable and incalculable hundreds of thousands of kotis of nayutas of eons and all the immeasurable wisdom and expedient means for fully cultivating all practices; they become a refuge for the worlds of gods and humans, they transcend the stages of all śrāvakas and pratyekabuddhas, and they are attended and revered by Śakra Devendra (King of Gods) and so on. So-called emptiness is dissociated from the sense organs and sense objects, has no [differentiating] characteristics and no [cognitive] objectivity, transcends all frivolous arguments (prapañca), and is boundless like empty space; all the dharmas (attributes) of a Buddha are successively born in dependence on it, and it is dissociated from the conditioned and unconditioned realms, dissociated from all activities, and dissociated from the eyes, ears, nose, tongue, body, and mind. [Then] is born the mind utterly without own-nature. Lord of Mysteries, such an initial mind the Buddha has declared to be the cause for becoming a Buddha; although liberated from karma and mental afflictions, it still has karma and mental afflictions at its base. 
The world will venerate [such a person] and should always make offerings to him. ${ }^{37}$

Yixing 一行 (683-727 CE), cited in Jiu Tang shu 舊唐書, 35.1307:

則王仲任、葛稚川之徒，區區於異同之辨，何益人倫之化哉？

What benefit, really, are the likes of Wang [Chong] and Ge [Hong]'s trifling distinctions to the transformation of humanity?

Song shu 宋書, 12.260-1:

宋太祖頗好曆數, 太子率更令官名何承天私撰新法。元嘉二十年, 上表曰: 261

Emperor [Wen] of Song (r. 424-53 CE) was very fond/curious (hao) of $l i$. Director of the Watches for the Heir Apparent He Chengtian privately wrote (si zhuan) a new method and submitted it in [443 CE]:

臣授性頑惰, 少所關解。自昔幼年, 頗好曆數, 耽情注意, 迄于 白首。臣亡舅故祕書監徐廣, 素舊時善其事, 有既往七曜曆, 每 記其得失。自太和至太元之末, 四十許年。臣因比歲考校, 至今 又四十載。故其疏密差會, 皆可知也。

'Your servant's given nature is obstinate and indolent, and there is little that [I] truly understand, but ever since childhood have [I] been rather fond/curious (hao) of li numbers [too], and [I] have indulged [my] emotions and poured [my] attention [therein] until [my] head has grown white. Your servant's late uncle, the former director of the palace library, Xu Guang, had for a long time excelled in these matters. $[\mathrm{He}]$ had a Seven Luminaries of the Past $l i$, and would always record its hits and misses, [which he did] from [between 365 and $371 \mathrm{CE}$ ] to [396 CE] for some forty-odd years. Your servant has continued to examine and compare every year now for another forty years, and thus [can I say that] its looseness and tightness, error and coincidence, can all be known.'

${ }^{37}$ Tr. Giebel $(2005,15-16)$. 


\section{Chapter 6}

Zhouyi zhushu 周易注疏, 8.167a-168a:

包犧氏沒, 神農氏作, 郘木為耤, 揉木為来, 未耨之利, 以教天 下, 蓋取諸益。日中為市, 致天下之民, 聚天下之貨, 交易而退, 各得其所, 蓋取諸噬嗑。

When the $[\mathrm{Fu}] \mathrm{xi}$ clan was gone, there arose the clan of the Divine Husbandman. [He] split wood to form the share, and bent wood into the handle, so as to teach all under heaven the advantages of ploughing and weeding. ... [He] made midday [the time of] market, to which he rendered [all] the people under heaven and assembled [all] the goods under heaven [so that they] made exchanges and retired, each obtaining what [they desired] ...

神農氏沒，黃帝、堯、舜氏作，通其變，使民不倦，神而化之， 使民宜之。易窮則變, 變則通, 通則久。是以自天祐之, 吉无不 利, 黃帝、堯、舜垂衣裳而天下治, 蓋取諸乾坤。剞木為舟, 炏 木為楫, 舟楫之利, 以濟不通, 致遠以利天下, 蓋取諸渙。服牛 乘馬, 引重致遠, 以利天下, 蓋取諸隨。重門擊柝, 以待暴客, 蓋取諸豫。重門擊㭛, 以待暴客, 蓋取諸豫。弦木為弧, 制木為 矢, 弧矢之利, 以威天下, 蓋取諸睽。

When the Divine Husbandman's clan was gone, there arose the clans of the Yellow Emperor, Yao and Shun. [They] bridged (tong) these switches (bian), making the people not tired, and [they] transformed (hua) them by [their] divinity (shen), making the people suited thereto ... [They] hollowed wood to form boats, and sharpened wood into the oars, [so as to teach] the advantages of boats and oars in fording where there is no bridge ( $b u$ tong) and in reaching distant parts to the advantage of [all] under heaven ... [They] domesticated oxen and rode horses, [teaching them] to pull heavy [loads] to distant parts to the advantage of [all] under heaven ... [They] strung wood to form bows, and sharpened wood into arrows, [teaching them] the advantages of bows and arrows in awing [all] under heaven.

Lüshi chunqiu 呂氏春秋, 24.9b:

養由基、尹儒皆六㙯之人也。荆廷嘗有神曰猨, 荆之善射者莫之 能中, 荆王請養由基射之。養由基矯弓操矢而往, 未之射而括中 之矣, 發之則猨應矢而下, 則養由基有先中中之者矣。

Yang Youji (fl. 597-558 BCE) and Yin Ru (?) were both men of the six arts. The Jing (Chu) court was frequently [visited by] a divinity (shen) named Ape. The best marksmen of Jing were all unable to hit it, [so] the king of Jing asked Yang Youji to shoot it. Yang Youji lifted his bow, drew an arrow and went forth. Before shooting, [he] centred (zhong) him at the nock (i.e. in aiming), and with one release, Ape took the arrow and went down. ${ }^{38}$

Shangshu zhushu 尚書注疏, 7.102b-103a:

羲和顛覆厥德, 沈亂于酒, 畔官離次, 俶擾天紀, 遐棄厥司, 乃 季秋月朔, 辰弗集于房, 韾奏鼓, 嫱夫馳, 庶人走, 羲和尸厥官 目聞知, 昏迷于天象, 以干先王之誅, 《政典》曰: 『先時者殺 無赦，不及時者殺無赦。』

\footnotetext{
${ }^{38}$ Tr. modified from Knoblock \& Riegel $(2000,619)$.
} 
The $\mathrm{Xi}$ and $\mathrm{He}$ [brothers] have now undermined their virtue, having deeply lost themselves in ale and abandoned office and quit camp, which has begun to disturb the net threads (ji) of heaven in the advanced abandonment of their charge. And so, on new moon's [day] of the last month of autumn, the chronograms did not gather in Chamber. ${ }_{\text {L04 }}$ (i.e. there was a solar eclipse); the blind musicians beat [their] drums, the [regional officers] galloped around, and the common people ran [in fear]. The $\mathrm{Xi}$ and He [brothers], impersonators to their office, heard nothing about it, being [now so] dim[-wittedly] astray in [matters of] heavenly signs, and [they] thus compel the punishment [appointed] by the former kings. The Canon of Governance says: 'He who is ahead of [the right] time shall be killed without mercy; he who is behind [the right] time shall killed without mercy.' 